\title{
On the Priorities of Comparative Advantage of
}

\section{Agro-industry Commodities: the way towards Economic}

\section{Transformation}

\author{
Yagoub Elryah (Corresponding author) \\ Assistant Professor, Researcher, Industrial Economies Research Institute \\ Industrial Research and Consultancy Center IRCC, Khartoum, Sudan \\ E mail: yagelryah@gmail.com
}

Received: February 10, 2019 Accepted: February 19, 2019 Published: February 20, 2019

doi:10.5296/rbm.v6i1.14374

URL: http://dx.doi.org/10.5296/rbm.v6i1.14374

\begin{abstract}
Economic development in Sudan has been facing more challenges than ever before in 2011 after South Sudan gets independence, where Sudan lost $75 \%$ from oil revenues. As a result, Sudan underwent structural reform that favored the concentrating in non-oil sector. Considering that agriculture has been largely contributing to the GDP, it seems that the main drivers' of economic growth. One of the most important questions regarding the New Structural Economics framework is (a) why industrialization becomes one the most determinants of country's economic development, (b) has Sudan's economic structure change over the years from 1980-2015, and (c) what the nature of that change? The purpose of this work is to identify the priorities of agro-industry commodities that Sudan has to focus on. It develops theoretical framework to investigate the sectoral composition trends of output and employment, and discusses these on the New Structural Economics framework. This study adopted two empirical models to analyze the collected data, which are obtained from different sources. Many of the hypotheses were supported. Major findings of this study are as follows. The analysis of RCA and PAM revealed that Sudan had lower costs in producing of agricultural and agro-industries commodities, except textiles manufacturing. The share of industrial sector in total employment and total output has declined during 2001 and 2015 period. Further analysis reveals that structural change has a negative impact on Sudan's economy and growth of labor productivity, the share of service in output has steadily increased, reflecting reallocation of employment away from agriculture towards service and trade activities. This study finds evidence of negative structural change on Sudan's economy and the share of value added manufacturing sector has decreased dramatically.
\end{abstract}

Keywords: agro-industries; comparative advantage; structural change; New Structural Economics. 


\section{Introduction}

The New Structural Economics framework to developing countries emphasizes the importance of comparative advantage for industries and manufacturing, a framework often labeled 'structural transformation. However, manufacturing and industrialization remain the main engines of structural transformation for all countries (Lin, 2011). One of the major issues in developing countries including Sudan is how to diversify and developing their exports, which is extremely difficult without transforming the production capacity from agricultural base to manufacturing processes. However, over the past two decades industrial performance and agricultural productivity were declined due the absence of proper economic policies to manage the endowments structure. In Sudan, the agro-industry is an integral segment of the transformational industries sector that is sensitive to structural change, and skilled labors. In order to remain competitive, agro-industry must be developed and adapt to technological progress. Due to close interaction between agricultural and industrial sectors, the agricultural products can be transformed and processed to benefit from added value and become more competitive in international markets.

One of the central issues in the international trade concerns the gains from trade and the importance of industrialization, and how to sustain the comparative advantages. Turning the question around we can ask what happens to the country when it loses its comparative advantages. This research offers a novel investigation of this problem in the light of the NSE framework. This research brings the literature on economic development in three grand divisions the gain from trade based on comparative advantages, industrial policy, and structural transformation. Using theoretical and empirical evidences, we investigate the priorities of comparative advantage commodities of agro-industries in Sudan.

Recently, there is now a very large literature assessing and evaluating the importance of comparative advantage and gain from trade. General evaluations include Andrei \& Zhang (2016), Brandt \& Zhu (2008), and Deardorff (2010). There is a large literature on structural change and economic transformation including Monga (2012), McMillan \& Rodrik (2011), Lin \& Treichel (2014). Recently, there has been a growing interest on adoption of industrialization helps on achieving the sustainability of economic growth, and how does the structure of industry factors affect the rate of economic transformation (Lin, 2011). There is also a rapidly growing literature on industrial policy, economic reforms, and institution, including its impact of productivity. Studies include World Bank (2014), Curtis (2016), Lin \& Chang (2009).

There is now a very large literature assessing and evaluating on structural change and industrial policy in developing countries (Lin, 2011; Duarte \& Restuccia, 2010; Lin \& Treichel 2014). Given that the research on the topics structural change, industrialization and diversification is increasing, many scholars are now adapting export policy for the goods that have comparative advantages, promoting industrialization with facilitating state and good institutions as the main determinants of economic development (Ju et al., 2015; McMillan \& Rodrik (2011). There is also rapidly growing literature on comparative advantage and diversifications in Sudan focus more on agricultural commodities (Imad-Eldin et al., 2010; Elryah, 2015; Ahmed et al., 2012). To bridge the gap in existing literatures, this study aims to identify the priorities of agro-industry commodities that Sudan has comparative advantage in. further, the intent is to fully develop theoretical framework to investigate the sectoral composition trends of output and employment.

In this study, we aim to make several contributions. First, whereas previous research has focused on examining the structural change and economic growth, we argue that 
policymakers and economists' scholars should also consider institutions building and economic reforms. We focus on identifying the trends of structural change in added value and employment. Second, we compare the comparative advantages of agro-industry commodities with comparative advantage of agro-industry commodities of other countries. Finally, we identify the priorities of agro-industry commodities that Sudan has to focus on, and discusses this on the NSE framework. Previous research has focused on the increasing development gap between developed and developing countries, when exploring the technological innovation, information, and communication technologies and the importance of technology in manufacturing and industrial growth (e.g., Lin \& Treichel, 2014; Fagerberg 2002; Kathuria $\&$ Raj, 2009). However, we argue that these approaches are narrowed focused and limited; research on structural transformation and comparative advantage need to consider a more comprehensive approach that will be abdicable to developing countries. Thus far, this paper has argued that following the comparative advantage might help a country to achieve structural transformation.

This study sets out to increase our understanding of structural change in Sudan by examining the comparative advantage of agro-industry commodities. All in all, this study is an attempt to answer the following questions: What is the role of structural change on labor productivity growth in Sudan? Are current economic policies in Sudan are enough strong to promote its agro-industries? Has Sudan's economic structure changed over the years from 1980-2015? And what the nature of that change? Which factors that influence structural change in Sudan? What lessons can Sudan learn from the industrialized economies? And how does industrial structure enhance the structural transformation? The major finding of this study is that, although agriculture has remained the main source of employment and income, we observe a significant shift in the labor allocation from agriculture and engaging in non-manufacturing activities. The analysis indicates that in most cases, Sudan's only the agricultural commodities are consistent with their comparative advantage and Sudan has been experiencing a negative structural change.

This study is organized into this introduction section and four additional to give a comprehensive and complete picture of the trends of structural change in Sudan during the past three decades in the context of NSE framework. It presents the NSE theoretical analysis, the comparative advantage, and gains from trade theories. Section three demonstrates an overview of Sudan's productive sectors and the need for developing the comparative advantages agro-industries; it presents an involvement of private sector in agro-industries in Sudan, and it gives analyses of value chains in the current industrial policies. It attempts to shed some lights on the role of agro-industries to accelerate economic growth and sustained the development. We present our empirical models and discuss the estimated results in section four. The final section gives the conclusion of the study followed by findings and policy implications.

\section{Structural Change, the New Structural Economics and comparative Advantage: Conceptual Framework and Theoretical-Empirical Literature}

In recent years, New Structural Economics has attracted considerable attention (Lin, 2012; Lin \& Monga, 2010; Lin \& Dinh, 2014). In particular, scholarship has focused on the relationship between endowment structures and economic growth. Ju et al. (2009), for example, suggest that developing countries can motivate firms to upgrade their factor endowments into high capital-intensity industries. However, some scholars have cast doubt on the idea of that upgrading the production scale needs a bigger market. According to Lin (2011) such a prospective does not address the problem of empirically economies of scale for small firms. Lin (2011) raises an important issues here; small firms may move up the 
industrial ladder in the upgrading the scale of production. In particular, policymakers and researcher have turned their attention to promoting industrialization based on comparative advantage. Lin \& Treichel (2014) propose that countries should focus on upgrading their endowment structure that enables developing of the productive sectors in line with the comparative advantages.

Before proceeding further, it is necessary to define clearly the key terminologies referred to in this study. In particular, it is imperative to clarify what we mean when we talk about "New Structural Economics framework" (NSE). The NSE is a strategy for achieving economic development. This framework proposed by Lin (2011), who argues that when a country develop its comparative advantage will perform better and will have lower economic volatility than other country. Thus, my use of the word "structural change" in this paper in influenced by Liews (1955) who defines the structural change or structural transformation by shifting the labor and other productive resources from agrarian economy to services or industrial sectors. It is an economic condition to diversify the economy, enhance the productive sectors and sustain economic growth. In particular, it is imperative to clarify what we mean when we talk about "comparative advantage". Comparative advantage (the closely related concepts of gain from trade and factor endowments) is an economic theory states that countries have to specialize in goods and services that producing by lower opportunity cost or more efficiently than other countries. For the purpose of this study, agro-industry refers to the process in which agricultural products are transformed to intermediary or final goods by using modern equipment. There have been numerous studies has employed the comparative advantage theory to emphasize that economic development can be achieved through industrialization and specialization in comparative advantages of commodities based on endowment structure for a particular country. Other than that, comparative advantage is specialization of a country in producing goods or services by lower opportunity cost than other entities (Ricardo, 1817). This concept goes with the free trade idea, so all countries will benefit from specialization in the goods and services produced by lower costs based on endowments structure. Having discussed the concepts of NSE, structural change, and agro-industry, let us now turn to a discussion on the limitations and boundaries of this study.

What policies are the most powerful in transforming the agricultural commodities into manufacturing goods and achieving economic transformation? Previous work on structural change may not only guarantee the success of this transformation, but also ensure it helps a country in identifying its comparative advantage. Robert \& Guillaume (2009) develop a two-section neoclassical growth model to analyze the China's structural transformation. They found that the economic reform between 1978 and 2003 has significant transforming China from agricultural sector into non-agricultural activities and it becomes one of the most rapidly growing economies in the globe. However, structural change requires a shift in employment and output shares.

While Barro \& Martin (1995) pointed out "if we can learn about government policy options that have even small effects on long-term growth rates, we can contribute much more to improvements in standards of living than has been provided by the entire history of macroeconomic analysis of countercyclical policy and fine tuning" (p. 17, 1995). We argue that in order for a country to transform into high value added, policymakers need to design effective development policies, which adds to the existing industrialization obstacles in the developing countries. A few studies also found that follows the comparative advantages enable countries to sustain competitiveness and growth (Levchenko \& Zhang, 2011).

Recent studies look at economic development as a dynamic process, coordination, and compensation. For instance, Lin (2011) argues "without the coordination and compensation, 
the process of economic development may slow, and the government should play an active role in facilitating structural change through mitigating the coordination and externality problem". Therefore, structural change is necessary for less developed countries to catch up the developed world through the productivity levels in the manufacturing sector (Duarte \& Restuccia, 2010). This will help the lower income economies to graduate into higher income level (Lewis, 1955).

It seems reasonable to argue that the sustainability of economic growth could be achieved by the interactions industrial upgrading and technological change. However, this view is not shared by Adam Smith, who believes that the market economy is applicable of sustaining the growth by allocating resources efficiently, where the structural transformation happens based the price system that determines which product will be produced and the resources go to the most productive sector. This system worked until the early of twentieth century, which Adam Smith forgets to take industrial upgrading and technological change into his account as main drivers for sustaining economic growth.

Building a new framework based on neoclassical and structuralism traditions developed by (Ju et al., 2015) who built a new approach that allows countries to adapt industrialization policy based on their endowments structure and specializing in comparative advantages of products that produced efficiently "by lower opportunity costs compared to other countries". The NSE often argues these factors with facilitated governments; the structural change could be achieved in less than two decades.

Compared to previous literature, our contribution of this study is to show that comparative advantage matters for within agro-industry relative Sudan's endowment structure, which consists in a novel approach to the New Structural Economics framework. Building on the structural model developed by Kongsamut \& Danyang (2001) which identifies the productivity growth in two sectors, agriculture and nonagricultural in China, this study has a base on the New Structural Economics and comparative advantage theories which state the importance of a facilitated state, the proper strategies, technological progress, industrial upgrade, and following the comparative advantages for stimulating economic growth, this view recommended by Lin (2011).

The empirical contributions, (Lin \& Treichel, 2014; Lin \& Chang 2009; Monga, 2012; Ju et al., 2015) have provided a solid evidence on the empirical merits of the factors gain from trade theory. In their works, the latent comparative advantage is revealed by its endowment structure and facilitated state on the factor content of trade. Lin \& Treichel (2014) argue that the increasing development gap between developed and developing countries rapid progress in industrialization, technological innovation, information, and communication technologies, which make it harder for the developing countries to catch-up and narrow this gap. In order for Sudan upgrades its industrial structure there is a need for improving the infrastructure. Rodrik (2013) argue that the structural change has a significant role in enhancing the labor productivity, and it associated with labor productivity.

In Sudan context, the share of agricultural sector in total employment has decreased during the past decade due to the shift from agriculture to mining sector. The share of workers in agriculture has relatively declined from 70 percent in 2000 to 45 percent in 2012. However, since the secession of South Sudan, Sudan has been facing economic shock, the decline in economic output, for instance between 2013 and 2016 the growth was negative. A limited number of studies on Sudan have been conducted concerning the evaluation the performance of transformational industries. Nevertheless, prominent study has appeared in the last decade using industrial sector and manufacturing. Taha (2016) investigates the relationship between 
the transformational industries and GDP. The study concludes that Sudan has been facing problems with transformational industries structure, the lack of industrial policy and business environment.

In addressing the issue of structural change and economic structures in Sudan, researchers and policymakers have considered several policies that give positive and significant impact on economic growth Felipe (1998) argues that countries experienced a faster economic growth (such as China, four tigers and New Industrialized Economies (NIEs) are followed industrialization to increase the manufacturing output. Similarly, Kathuria \& Raj (2009) found the higher economic growth that India achieved was through manufacturing and services sectors. Fagerberg (2002) investigates the importance of technology in manufacturing and industrial growth. In contrast, the findings of Lin \& Chan (2009) support the view taken in this paper. Previous research has shown that even the county with labor abundant has the ability to produce by lower opportunity costs.

This paper adopts the view that in order for Sudan to engage in international trade, there is a need to develop and transfer its agricultural commodities into manufacturing and final goods, besides allocating the labor to high skilled and productivity sector, increase the shares of employment in productive sectors, reduce the shares of employment in services sector, motivating firms and factories to improve productivity (Herrendorf \& Valentinyi, 2014; and Rodrik, 2013). This section has focused on literature review. The next part of this paper will discuss data collection and proposed methodology.

\section{Data, Proposed Methodology, and Limitations}

\subsection{Data Collection}

In Sudan, numerous studies have uncovered the agro-industry and it role in transforming the economy to catching up the developed world and thereby achieve the expected economic development. The data for the analysis span the period 1980 to 2016 and are taken from secondary data from different sources. Some data were collected from the World Bank, Trade map, and the Sudanese Ministry of Industry publications. Our analysis also uses the survey conducted by Industrial Research and Consultancy Center (IRCC) between 2012 and 2016, which covers 863 industrial companies across the country.

Table 1. List of agro-industry and agricultural raw materials commodities

\begin{tabular}{|l|l|}
\hline \multicolumn{1}{|c|}{ Agro-processing } & Agricultural Raw Materials \\
\hline Sugar & Cotton \\
\hline Textiles & Livestock \\
\hline Meat Processing & Gum Arabic \\
\hline
\end{tabular}

Source: Authors' construction

Gum Arabic, textiles, cotton, sugar, livestock, meat-processing were among the selected commodities that have been considering as promising products in the five-year economic reform 2015-2019. We conduct an in-depth survey on agro-processing factories in Sudan from November 2016. Some data were collected from the comprehensive industrial surveys 
of 2001 and 2005 conducted by Ministry of Industry and collaboration with IRCC.

The logical of choosing this period from 1980 to 2016 is that in this period, going back from the successful strategic plans of 2000-2011, the years followed a signed the comprehensive of the general peace agreement and the ongoing economic reforms and implementation of the five-year program for economic reform of 2015-2019. Sudan has been witnessing a negative economic growth especially after losing nearly $75 \%$ of the oil revenues. Some data were collected from published reports collected by Ministry of Agriculture and Agricultural Research Institute on capacity and actual agro-industry, added value of product industry, the feasibility of the location of agro-industry, and the mechanism of prediction of development. Our main focus as mentioned earlier will be on agricultural raw materials (livestock, Cotton and Gum Arabic) and agro-industries such as Sugar, meat processing, and textiles manufacturing as shown in table 1.

\subsection{Research Model and Hypotheses}

In this paper, the research model incorporates output of industrial sector, share of employment, and value added context as important determinants of structural change. in Sudan's economy has been derived by oil industry and there is a deterioration on productive structure that weakened diversification of productive activities, although Sudan has a comparative advantage in producing agricultural and agro-industry commodities by lower cost compared to construction sector, where the attracted foreign investments were concentrated. In our view if there are good governance and institutions, agro-processing is a promising sector and able to transform the agricultural commodities into high added value (such as leather, meat-processing, cotton and gum Arabic). The following hypotheses are developed to be tested in this study.

\section{H1: Sudan has a comparative advantage in agricultural commodities;}

H2: High value added will be positively associated with the structural change;

H3: High share of employment will be positively associated with the structural change.

\subsubsection{Measuring Comparative Advantage:}

Comparative advantage can be measured by two different methods. Firstly, it can be measured by the Revealed Comparative Advantage (RCA) developed by Balassa (1977), which has been used widely among scholars, (such as Krugell, 2009 and Deardorff, 2010). The following commodities are considered: (food and beverages, textiles, leather, leather products, and footwear) to identify which products have a most comparative advantage, the Revealed Comparative Advantage (RCA) method is the best method for analyzing the comparative advantage, which can be expressed as follows.

$$
C A=\left(\frac{X i, j}{X w, i}\right) /\left(\frac{X i, t o t}{X W, \text { tot }}\right)
$$

Where:

CA refers to comparative advantage, $\mathrm{X}_{\mathrm{i}, \mathrm{j}}$ is a country $\mathrm{i}$ 's exports of product $\mathrm{j} ; \mathrm{X}_{\mathrm{i}, \text { tot }}$ represents the country i's total exports; $X_{w, j}$ refers to the world's (all countries) export of product $j$; and $X_{w, t o t}$ is the total exports in the world. However, according to the model, $\mathrm{CA} \geq 1$ means that this product has a comparative advantage, by contrast when $\mathrm{CA}<1$ that means that this product has no comparative advantage. 


\section{Macrothink}

Secondly, the PAM is also used to measure the comparative advantage delivered by (Monke and Person, 1989) of the selected commodities in table 2. It measures the input use efficiency and the degree of state interventions in the market.

Table 2: Policy Analysis Matrix (PAM)

\begin{tabular}{|l|l|l|l|l|}
\hline \multirow{2}{*}{ Price } & \multicolumn{3}{|c|}{ Cost } & \multirow{2}{*}{ Profit } \\
\cline { 2 - 5 } & Revenues & \multicolumn{1}{|c|}{$\begin{array}{c}\text { Domestic } \\
\text { factor }\end{array}$} & $\begin{array}{c}\text { Tradable } \\
\text { inputs }\end{array}$ & \\
\hline Private price & $A$ & $B$ & $C$ & $D=(A-B-C)$ \\
\hline Social Price & $E$ & $F$ & $G$ & $H=(E-F-G)$ \\
\hline $\begin{array}{l}\text { Effective } \\
\text { divergence }\end{array}$ & $I=(A-E)$ & $J=(B-F)$ & $K=(C-G)$ & $\begin{array}{l}L=(I-J= \\
D-H)\end{array}$ \\
\hline
\end{tabular}

Financial Cost Benefit ratio (FCB), Domestic Cost Resources ratio (DRC), The Effective Protection Coefficient ratio (EPC), and the Equivalent Producer Subsidy (EPS)

As general known that structural transformation may generate both dynamic and static gains. Dynamic gains are based on positive externalities over time, where firms will have access to technology and skilled labor. Productive structural transformation is transformation process that simultaneously generates productivity growth within sectors and shifts labor from lower to higher productivity sectors to create more and higher-productivity jobs. According to the theory if value of $\mathrm{D}$ and $\mathrm{H}$ are positive the market will be competitive and makes profit without being constrained by taxes. If the price of labor is stable $(D>0)$ and the value of $(H<0)$ the market can be classified having no comparative advantage. This makes PAM a suitable method for helping policy makers in making their priorities from alternative commodities.

\subsubsection{Measurement Structural Transformation}

Three measures can be used to calculate the structural transformation, the share of employment shares, final consumption expenditure shares and value-added shares of economic sectors. Employment shares are calculated either by hours worked or by workers per sector. The final consumption expenditure shares and value added shares can also be estimated by the current prices "nominal shares", or by the constant prices "real shares". We build our model based on Rogerson (2008) assuming that increases in productivity in agro-industry commodities raise the GDP. In this study, we use the share of employment and value-added shares in economic sectors to measure structural transformation.

$$
\mathrm{Y}_{\mathrm{it}}=\mathrm{A}_{\mathrm{it}} \mathrm{K}_{\text {it }}^{a} L_{\text {it }}^{1-a}(1)
$$

With few modification of growth accounting model, we develop a simple model of contribution of production sectors to the total output. We compute the economic sectors (agriculture, industry, and services) using Cobb-Douglas production technologies as follows.

$$
\begin{aligned}
& \mathrm{Y}_{\mathrm{AGRt}}=\mathrm{A}_{\mathrm{AGRt}} K_{\text {AGRt }}^{1-a} L_{\text {AGRt }}^{1-a}(2) \\
& \mathrm{Y}_{\text {INDt }}=\mathrm{A}_{\text {INDt }} K_{\text {INDt }}^{1-a} L_{\text {INDt }}^{1-a}(3)
\end{aligned}
$$




\section{$Y_{S S t}=$ AsSt $K_{S S t}^{1-\varpi} L_{S S t}^{1-\alpha}(4)$}

Yit refers to GDP in sector $\mathrm{i}$ at year $\mathrm{t}$; Lit is employment, and $\mathrm{K}_{\text {it }}$ represents the capital stock

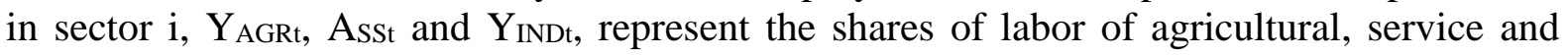
industrial sectors, respectively. We assume L represents the total of employment; $\mathrm{L}$ is a number of workers in the agricultural sector (AGR), industrial sector as (IND), and (SER) represents service sector, $\mathrm{n}$ is a number of national agricultural schemes and agro-processing factories, where $\lambda i$ is the shares of the agricultural sector, which can be calculated as follows.

$$
=\sum_{i=1}^{n} \frac{L_{i}}{L}=\frac{L_{A G R}}{L}+\frac{L_{I N D}}{L}+\frac{L_{S E R}}{L}=\sum_{i=1}^{n} \lambda_{i}
$$

The pattern of structural transformation in the recent developed and transitional economies has been characterized by a shift away from lower traditional activities to high skilled labor and dynamic activities. Therefore, we extract data on value-added share shares and sectoral employment in both agricultural and industrial sectors over the period from 2005-2013. The shares of added-value are calculated using current prices and the export shares as percentage of GDP per sector. The shares of employment are also calculated by the number of hours worked in each sector.

The Value-added Shares can be computed as (X) "real shares", (Xi) is used for nominal value in both agricultural and industrial sectors. The export shares by agricultural (AGR), industrial (IND) and service (SER) sectors as percentages of GDP. Value-added share can be estimated as follows.

$$
=\sum_{i=1}^{n} \frac{X_{i}}{X}=\frac{X_{A G R}}{X}+\frac{X_{I N D}}{X}+\frac{X_{S E R}}{X}=\sum_{i=1}^{n} \phi_{i}
$$

$\theta \mathrm{i}$ represents the shares of agricultural, industrial and service sectors in total value added.

In this study, we measure structural change by following McMillan and Rodrick (2011), who express per capita can be driven from activity rate $\frac{L_{\mathbb{R}}}{P O P_{\mathfrak{E}}}$ and labor productivity $\frac{G D P_{E}}{L_{L}} \quad$ components are as follows.

$$
P C G D P_{\mathrm{t}}=\frac{L_{t}}{P O P_{\mathrm{t}}} \times \frac{G D P_{\mathrm{t}}}{L_{\mathrm{t}}}
$$

However, the GDP per capita was improved during the years from 2000 to 2010 driven by labor productivity, but during the last years the labor productivity dropped by $70 \%$, as a result the growth of GDP per capita declined. Now we can decompose the labor productivity component as follows.

$$
\begin{gathered}
\delta P_{t}=P_{t}-P_{t-1}=\sum_{j} \theta_{j, t-1} \times \\
\left(P_{j, t}-P_{j, t-1}\right)+\Sigma_{j}\left(\theta_{j, t}-\theta_{j, t-1}\right) \times P_{j, t}
\end{gathered}
$$

Where $\sum_{j} \theta_{j, t-1} \times\left(P_{j, t}-P_{j, t-1}\right)$ is weighted average within sector productivity growth (sectoral employment share), and $\Sigma_{j}\left(\theta_{j, t}-\theta_{j, t-1}\right) \times P_{j, t}$ represents structural change term.

$$
\Delta P_{t}=\sum_{i=1}^{n} \theta_{i, t-k} \Delta p_{i, t}+\sum_{i=t}^{n} p_{i, t} \Delta \theta_{i, t}
$$

Whereas Pt and pi,t represent the productive sectors; $\theta \mathrm{i}, \mathrm{t}$ is the share of economic sectors in total employment; $\mathrm{t}$ is the time (1980-2015). The $\Delta$ refers to the change in productivity $\mathrm{t}-\mathrm{k}$ and $\mathrm{t}$. 
Our study is broadly complementary to a recent literature examining the gain from trade of developing countries over time. In linking the priorities of comparative advantages of agro-industries and the process of structural transformation, our study is closely related to the study carried out by Brandt and Zhu (2008) and to the study of economic reforms and the evolution of China's total factor productivity (TFP) by Curtis (2016). One of the main differences of our study from these studies in that we consider two sectors, specifically (agriculture and industry) and that we use the model to identify the comparative advantages in both agricultural and agro-industry commodities and the linkages between these sectors. Our paper is also related to Dekle (2009) who analyses of China's structural transformation and (Andrei \& Zhang, 2016) who evaluate the comparative advantage in both developed and developing. Our focus in this study is instead on the agro-industries as the best strategy for achieving structural transformation in Sudan.

\section{Overview of Sudan's Economic Policies and the Need for Developing Comparative Advantages of Agro-industries}

\subsection{Brief Overview of Sudan's Economic Development Efforts}

Sudan is considered an agricultural country with nearly $70 \%$ of the population working in this sector. However, during the past two decades the share of agriculture in total employment has declined to $33.7 \%$ (World Bank, 2017). Annually, Sudan has been producing and exporting many agricultural commodities, which contribute 34\% of Gross Domestic Product (GDP). From 1980s until the early 1990s, Sudan has become one of the first largest exporters of Cotton and livestock, and it has emerged leading exporters for Gum Arabic with $80 \%$ of global market share (Chikamai, 1996; Macrae \& Merlin, 2002)

Historically, agricultural sector in Sudan was described as "bread-basket" for Arabic countries (Kaikati, 1980). Further, Sudan has learnt from other developing countries, especially after its independence that exporting agricultural commodities as raw materials are not beneficial for an economy. Agricultural commodities such as Cotton, Gum Arabic, and livestock continue enhancing the national economy through the allocation of financial resources for development. For decades, Sudan started exporting primary agricultural commodities as raw materials and is still lagging behind, unable to benefit from the availability of resources including human and natural, besides the good climate location. The economic reform policy provided the framework to concentrate on agro-based industries, which becomes one of the alternatives to diversify Sudan's economy.

In the early 1960s, Sudanese government began a series of ten-year plans to develop the productive sectors. One of the major programs was the establishing of textiles factories, edible oil processing industries, flour Industry, and other food-processing industries. As part of broader structural adjustment programs in the late 1970s, Sudan has attracted the Arabic financial resources and mobilized domestic savings to build the national economy, where many sugar companies were established. However, in early 2000, the Sudanese government attracted China's foreign direct investment (FDI) to discover and produce oil products. Since then until 2011, the economic policies have focused on producing and exporting crude oil and ignored the other productive sectors such as agriculture and manufacturing. However, these policies have longer support the process of economic development, especially after Sudan lost $75 \%$ of its oil revenues due to the secession of South Sudan. Sudan is rich in other natural resources and considered as one of the best agricultural countries in the world that hold reserves of fishing, forestry and some of the underexploited sectors that have huge economic development potential.

Sudan was one of the most fasted growing during the years of 2005-2010, due to producing 
and exporting oil. However, the years followed the secession of South Sudan in 2011 accelerated all these trends. Sudan has been facing an economic shock that is a negative economic growth and lower production of both agricultural and industrial outputs. As a result, two economic reform plans were successfully implemented to return the economy to normal.

In recent years, the economic shock created by the independence of South Sudan has been decreasing the Sudan's economic growth. Therefore, the declining of economic growth of Sudan has been a common phenomenon in recent years. However, the concentration on oil industry has weakened the economic structure, which missed the opportunity to develop another productive sectors such as agriculture and manufacturing.

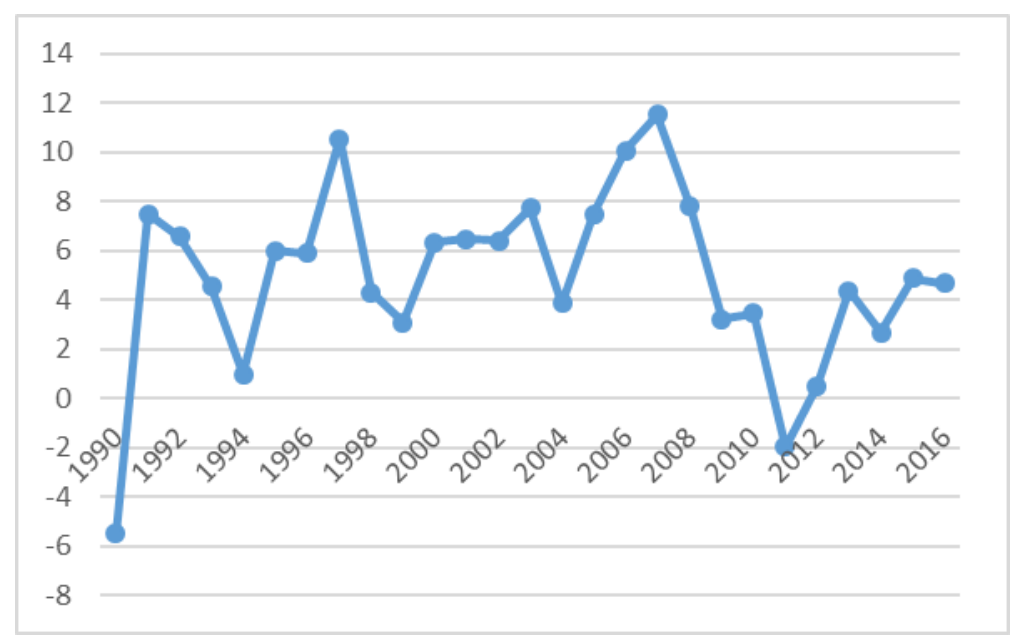

Figure 1: Sudan's Real Economic Growth 1990-2016

Source: World Bank, 2018

Figure 1 displays the evidence that the negative and fluctuation in Sudan's economic growth, for instance in 1991 and 2011, where the growth was negative $-6 \%$ and $-3 \%$ respectively. At the end of 2016, real growth was $2.8 \%$ supported by oil-transit fees, agriculture, and minerals, and is projected to reach $7.2 \%$ by the end of the five-year economic reforms program. However, in the coming years, economic growth and development are expected to grow, especially after the government initiated economic policies that allow the industrial and manufacturing sector leads the growth.

\subsection{Agricultural Production and Trade}

Sudan's most important natural resource is its agricultural land. However, "it was widely regarded as the future breadbasket of the Arab nations, a vast, fertile land with abundant water from the Nile watershed" Stephen (1990).

As shown in the table 3 that the area of the land available for agriculture was $250.429 \mathrm{~km}$ as in 2010. However, between 2013 and 2014 the agricultural sector contributes $31.1 \%$ and $34.2 \%$ respectively. In 2009 , the share of agriculture to total manufacturing was $60 \%$ as raw materials and $80 \%$ of non-petroleum exports are agricultural products (IFAD, 2009). 
Table 3. Land use in Sudan

\begin{tabular}{|l|l|}
\hline Item & $\begin{array}{l}\text { Area ('000 } \\
\text { ha) }\end{array}$ \\
\hline Land area & 237,443 \\
\hline Area under water & 12,986 \\
\hline Arable land & 84,034 \\
\hline Cultivated land & 17,471 \\
\hline Uncultivated land & 66,563 \\
\hline Forest and wood land & 64,360 \\
\hline Other & 49,569 \\
\hline Total area & 250,429 \\
\hline
\end{tabular}

Source: National Statistics Bureau, 2010

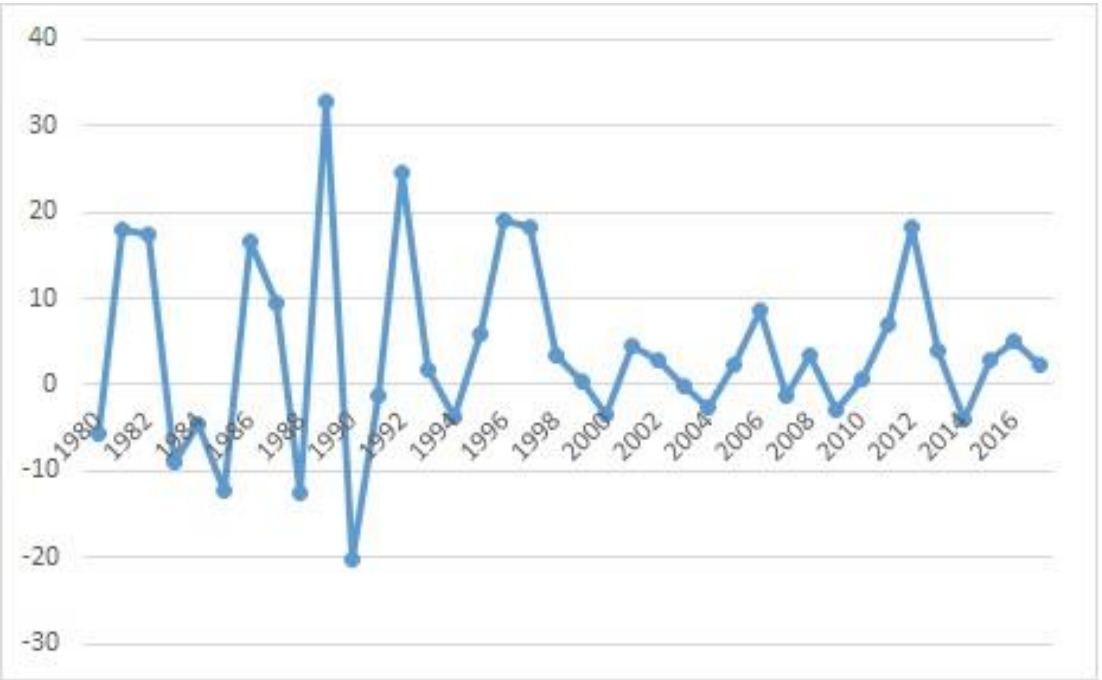

Figure 2: Agricultural, value added growth, 1990-2016

Source: World Bank, 2018

Figure 2 illustrates the annual agricultural, value added growth rates over the period from 1990 to 2016. The figure shows that value added growth rates has been fluctuating over years. However, during the years followed the independence of South Sudan, the contribution of agriculture in GDP dropped from 19.7 percent in 2012 to -7.4 percent. The five-year program was initiated to increase productive among sectors, as a result the agriculture's share of value-added was increased up to 6.7 percent in 2016. The major reason for dropping in outputs is that there is a change in economic policies, which move towards producing and exporting oil, which caused a decrease in agricultural outputs. 


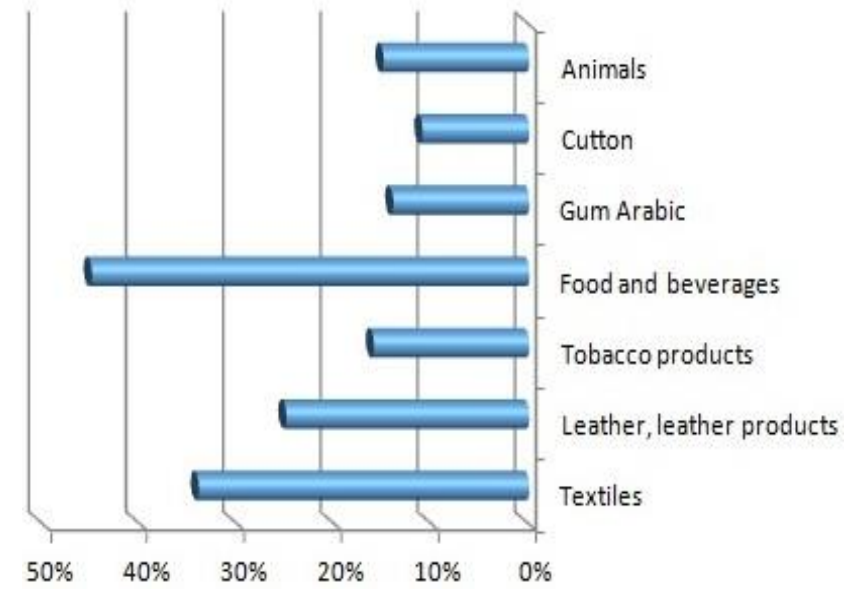

Figure 3: the added values of agro-industry products in 2014 Source: UNIDO INDSTAT2, 2016, at current prices (in US\$)

Since the secession of South Sudan in 2011, Sudan has lost $75 \%$ from its oil revenues. There has been consensus on an initiative new strategy to rebuild the economy and promote industrial policy. The figure below shows the added values of agro-industry products in 2014 . However, from the late 1999 till now the Sudan's economy was drastically affected by civil conflicts and sanctions by western countries. In the years followed the succession of south Sudan, the agricultural productivity has significantly improved and the only sector that requires less investment and saving because the infrastructure in agricultural sector was developed earlier. The production of cotton, gum Arabic and peanuts was relatively high between 2013 and 2016. Sudan is characterized and endowed with fertile agricultural lands, varied climates and vast virgin areas. For instance, only 40 million hectares have been cultivated out of 350 million hectares. Besides that, the availability of water resources such as rains, rivers, underground water, various forests fruits, livestock and diversity of climate qualifies Sudan to produce the agricultural commodities by lower opportunity costs.

\subsection{Structure of Sudan Economy}

After getting its independence and in the first phase of industrialization why does Sudan fail to focus on agro-based industry instead of exported its agricultural commodities as raw materials? Is the current industrial policy applicable to transform Sudan economy and thereby benefits from the added value of agricultural commodities? Sudan is endowed with cheap labor supply and rich natural resources. However, if there is facilitation by government, the agro-industry sector could transform the country to accelerate the economic development and thereby dragged out of the least developing countries. However, the country was characterized by large productivity gaps among economic sectors, and there is a large shifts of labor out of agriculture to other sectors, what their contribution to aggregate productivity growth. This gap could be an important engine of growth (Lewis, 1954).

Initially, Sudan started exporting primary agricultural commodities as raw materials. Since the early 1980s, the East Asian countries have successfully adopted industrial policies that transferred into more industrialized nations. Sudan is still lagging behind, unable to benefit from the availability of land, labor, structure, climate, and location. The economic reform policy provided the framework to concentrate on agro-based industries, which becomes one of the alternatives to diversify Sudan's economy. 
Another challenge for Sudan economy is the existing technology in the manufacturing sector was evaluated over the past few years, which robust development is anticipated to delay for foreseeable future. Our argument is that Sudan continues to develop and to build the agro-industry, the availability of raw materials, the existing of agricultural schemes, and skilled labor for agriculture. Although Sudan has a best industrial structure among African countries, the share of the sector in value added was weak. There is a need for major reform to the agricultural and manufacturing sectors to create opportunities for businesses to set up a companies and joint venture, enhance the new development opportunities, and develop the productive sectors as a whole. In Sudan, there has been a change in the structural of labor market during the past two decades, for instance, there are many workers changed away to nonagricultural activities. On one hand, the employment shares for agricultural sector were declined to 55 percent in 2012 down from 70 percent in 2005. This decline in the share of employment of agriculture is caused by shifts from the rural to the urban areas. On the other hand, the labor market in Sudan characterizes by a dominant public sector compared to the private sector. Although there is a shift to urban areas where industries exist, most of the workers are involve away from industrial sector, where it needs high-skilled labors.

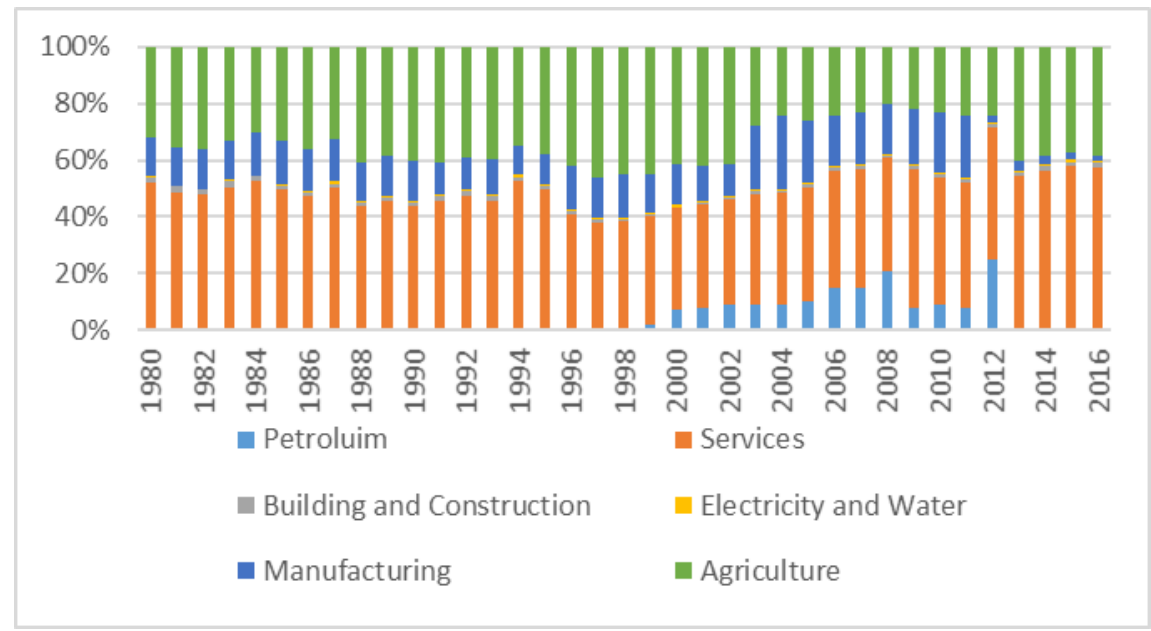

Figure 4. Composition of the Sudan's GDP 1980 - 2016 (in \%)

Source: The Central Bank of Sudan annual reports (various issues)

Figure 4 shows the trends of Sudan's economic sectors in the composition of the GDP. The contribution of petroleum sector to the GDP increased from 2\% in 1999 to $25 \%$ in 2012 and it was declined to lower than $1 \%$ afterwards. In contrast, the contribution of agricultural sector to GDP in 1999 was $48 \%$ and starts declining to about $31 \%$ in 2010 . The contribution of service sector to GDP taking over the lead after the deterioration of oil revenue after 2008 . The share of services' in value-added has steadily improved over years. Petroleum sharply declined from 21 percent to 8 percent in 2010, before gradually declining to 3 percent in 2012.However, during this period there was no or only a slight change in the other sectors including the industrial sector, building and construction, and electricity and water..

The shift from agrarian base to industrial and manufacturing sector happens either by the shares of value-added or employment shares in economic sectors. In the early stages of structural transformation, the share of employment in manufacturing sector expected to increase higher than services sector. 


\section{Macrothink}

In Sudan the situation is opposite, as shown in the figure above, that the contributions of agricultural sector starts decline 46\% to 25\% from 1997 until 2011, however, during the same time period it witnesses the boom of oil industry, as a result the value added share of industry increased from $14.5 \%$ in 1997 to $28 \%$ in 2012, then it declined to 2.9 in 2016 . The share of service in value added has rapidly increases from $47.2 \%$ in 2011 to $58.1 \%$ in 2016.

Historically, Sudan kept it is economic policy related to agriculture and it continues to promote economic growth. However, as shown in figure 6, between 1960 and 1997 the agricultural outputs contribute around 36.2 percent of the GDP. However, the landscape of Sudan's economic has changed over the years from 2000 to 2012, where the structural change has a negative impact where it moved from agriculture to services, and later to mining. Furthermore, it declined due to the exporting the oil in the early 2000s. That is the gross value-added of agriculture decreases from 43 percent in in 1995 to 27.5 percent in 2011.

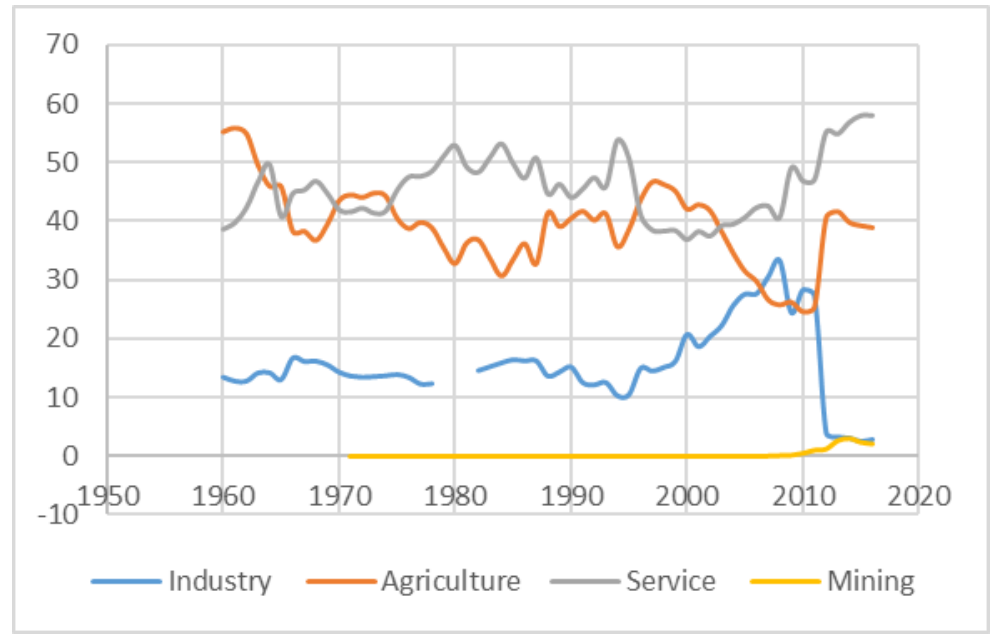

Figure 5: Gross value-added by sector in the GDP (1960- 2016)

Source: World Bank (2018)

As a result of Sudan's loss of $75 \%$ of the oil revenues, the gross value-added of agriculture has been increased from 27.5 percent in 2011 to 40 percent in 2016. The share of mining increased steadily during the years following the independence of South Sudan.

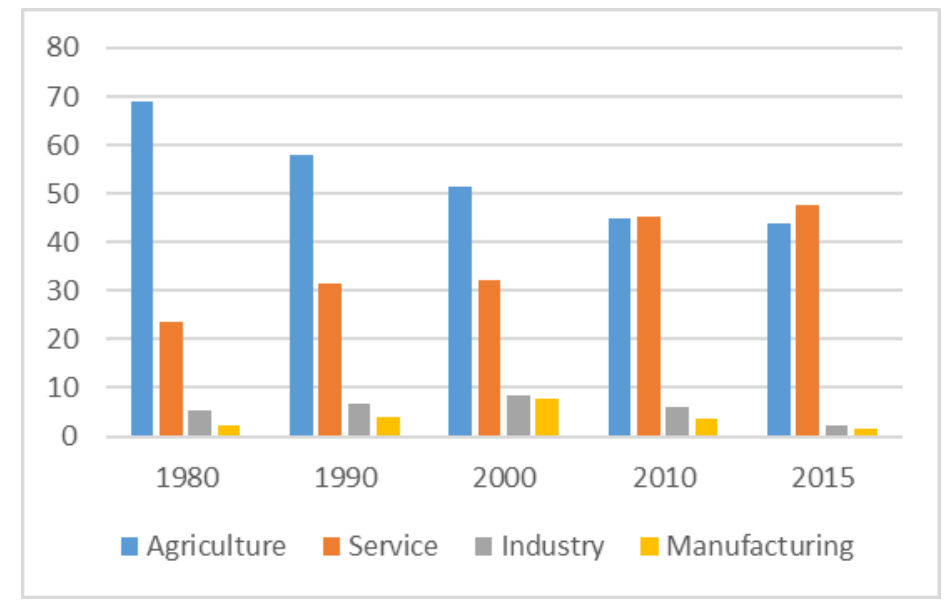

Figure 6: Employment shares by sector as a percentage of employment (1990- 2017) Source: World Bank (2018) 
A similar trends are found for industrial sector, where the gross value-added declined during the past decade from 32 percent in 2009 to 2.9 percent in 2015. The service had the highest shares among economic sectors in terms of value added and share of employment in 2015.

The behavior of relative productive sectors in Sudan depicted in Figure 6 is associated with the process of structural change across sectors. The structural transformation is referred in the development literature that value-added shares of economic sectors. Currently, agriculture employs 32 percent of the labor force, so that the shift from agriculture to services characterizes the process of structural change since the 2000s. In Figure 4 we show the ratio of value-added in services (including market and non-market services) to goods production over the periods from 1975 to 1993, and from 2000-2017, where service has steadily increased.

The Sudan government has been adopting economic policies to achieve economic development through the encouragement of industrialization, especially import substitute industry products. However, there are many obstacles which hindered the effort for achievement of industrial development, due to the fact that the share of manufacturing industry in GDP at factor cost 34\% in early 2000 and decline to $24 \%$ in 2014, while the employment in the industrial sector was $2 \%$ according to study carried by the World Bank (2016).

Sudan has had persistent difficulties in lower productivity and lack of economic policies regarding the agricultural sector, which spurred its government to take many initiatives to ensure that agricultural commodities should not be exported as raw materials. Historically, Sudanese policymakers have taken the position that the energy industry generates adverse of balance-of-payments and has ignored other productive sectors such as agricultural and agro-industrial sectors. However, with the secession of South Sudan, as a result, Sudan lost $75 \%$ from its oil revenues.

Since the early 2000s until 2011, the economic policies have focused on producing and exporting crude oil and ignored the other productive sectors such as agriculture and manufacturing. However, over the past 60 years, agro-industrial sector has significantly contributed to the economic growth, for instance, the share of agro-industrial sector to value added was 40 percent and characterizes by the strong presence of textiles manufacturing and food industry, which contributes around $70 \%$ of the value added of total manufacture. However, these policies have longer support the process of economic development, especially after Sudan loses $75 \%$ of its oil revenues due to the secession of South Sudan. Sudan is rich with other natural resources and considered as one of the best agricultural countries in the world that hold reserves of fishing, forestry and some of the underexploited sectors that have huge economic development potential.

Sudan has a higher level of industrial diversification and the agro-industries are not developed yet due to the absence of proper economic policies, the lack of the existence technology and skilled labor. The productivity of Sudan's agro-industrial sector, the table below demonstrates the average value added per employee compared to the value of overall manufacturing. Sugar manufacturing and flour mills are the most drivers' agro-industry growth in Sudan. For instance, Sudan is third largest producing and exporter of Sugar after Egypt and South Africa, Kenana Sugar Company Limited is leading Sudanese Sugar companies. On the other hand, wheat flour is also one of the most developed agro-industries in Sudan. The global market share for wheat flour was $16.8 \%$ of the world grain. 


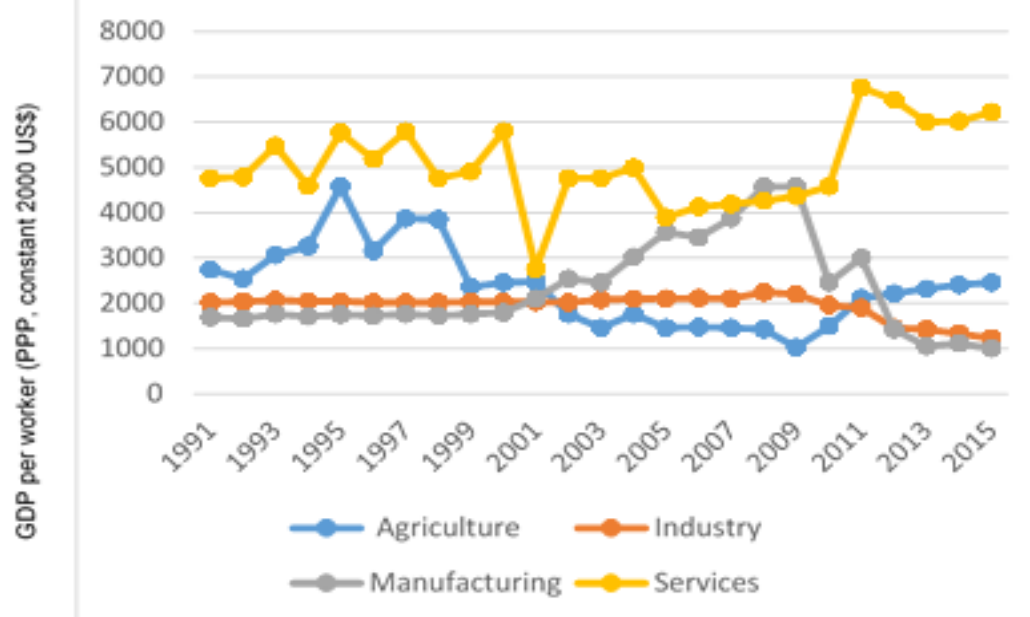

Figure 7: Sectoral labor productivity (GDP per worker), 1991-2015

Source: Sudan's Economic Survey 1995-2001, Population and Housing Censuses 2012, and 2014 and World Bank (2017)

Figure 7 shows the nature of structural change in Sudan over the past three decades. The GDP per worker in the service sector has been always on the top, although it experienced a decline in 2001. The highest GDP per worker in agriculture was in 1995. While Sudan experienced some positive structural change between 2000 and 2010 due to increase the manufacturing in oil sector, at the same time the employment in agriculture was declined. Since 2010, the employment rate has decreased among skilled labor and it has negative impact on economic activity, which results in the wrong direction of structural change. On the other hand, the shares of agriculture and service in value added were increased to 46.4 percent and 58 percent respectively after 2011. On the one hand, in 2010 the share of industrial sector in value added was 28.4 percent. As a result of secession of South Sudan the sector was collapsed and declined to 2.9 percent in 2015.

\subsection{Development of labor's productivity}

The Sudan government has been adopting economic policies to achieve economic development through the encouragement of industrialization, especially import substitute industry products. Sudan's persistent difficulties in lower productivity and lack of economic policies regarding the agricultural sector, which spurred its government to take many initiatives to ensure that agricultural commodities should not be exported as raw materials. Historically, Sudanese policymakers have taken the position that the energy industry generates adverse of balance-of-payments and has given little attention to other productive sectors such as agricultural and agro-industrial sectors. However, with the secession of South Sudan, as a result, Sudan lost $75 \%$ from its oil revenues. However, Sudan starts exporting primary agricultural commodities as raw materials. The economic reform policy provided the framework to concentrate on agro-based industries, which becomes one of the alternatives to diversify Sudan's economy. 


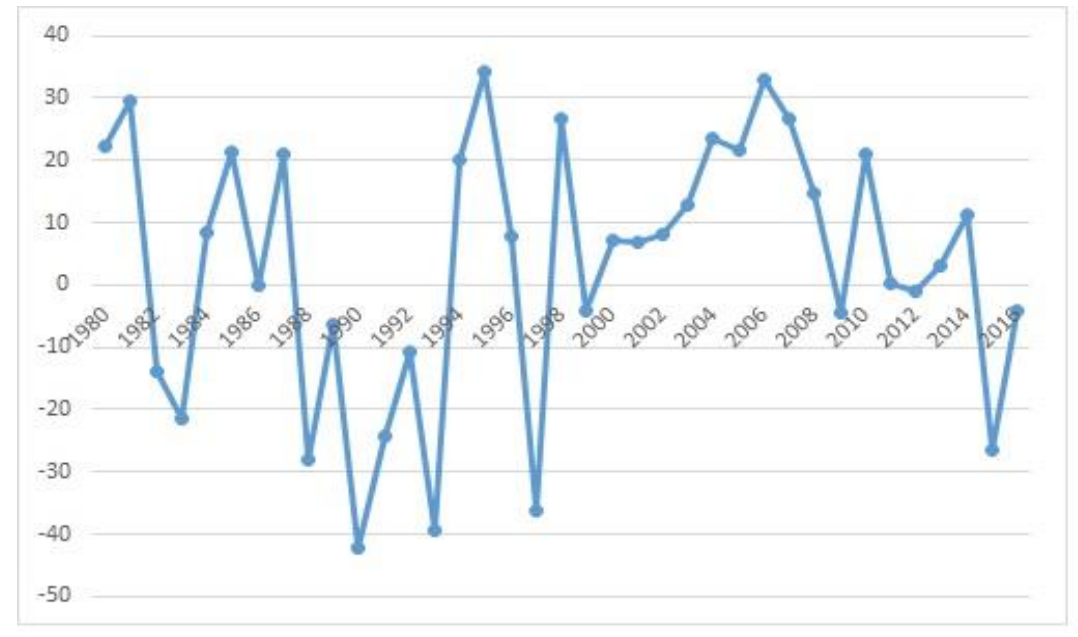

Figure 8: GDP per person employed (constant 2011 PPP \$) 1991-2017

Source: World Bank, 2018

Figure 8 shows how the labor productivity growth was fluctuating during the past years. It witnessed substantially declining the years $1994(-21 \%)$, and it sharply declined over the period from 1988 to 1998 by $-28 \%$ in average. However, from 2000 until 2007, the productivity growth was improved and it reached the highest level of $34 \%$. However, the productivity growth was declining in the years followed the independent of South Sudan in 2011. This can be justify to the fact that Sudan has lost $75 \%$ of oil revenues, also during the period many people are moved to major cities, thereby decreasing labor in agricultural sector. As a result, productivity per worker is increased only in agricultural sector. However, there is a need to upgrade skills among workers in industrial and manufacturing sectors, which need first adequately to develop the manufacturing sector and educational system.

Another challenges is that the private sector is unable to meet the unemployment rates especially among college and university students, which estimated to reach 2.5 million by 2020 . However, in 2015 the industrial and manufacturing sector employs nearly $14 \%$ of the labor force and the output per labor dropped by $30 \%$ from SDG18,804 in an early 1980s to 5833.4 in 2016. This can be justify to the absence of industrial strategies and lower investment in education that would raises the skills and knowledge among workers.

Sudan has a good industrial structure and the level of industrial formation as a ratio of the manufacturing sector to GPD continues to increase after the adapting industrial policy that attracted foreign businesses to invest in agriculture that can be manufactured. However, if the facilitation government exists, the agro-industry sector may transform the country by accelerating economic development and thereby dragged out of the least developing countries. Figure 9 shows the fluctuation of the growth of labor productivity by sectoral level over the years from 1991 to 2015 . The growth of labor productivity in agriculture was the lowest among sectors, where there was no growth of labor productivity in the years 1998 and 2006. The sectoral productivity slowed down in 1998 has affected virtually all economic sectors. 


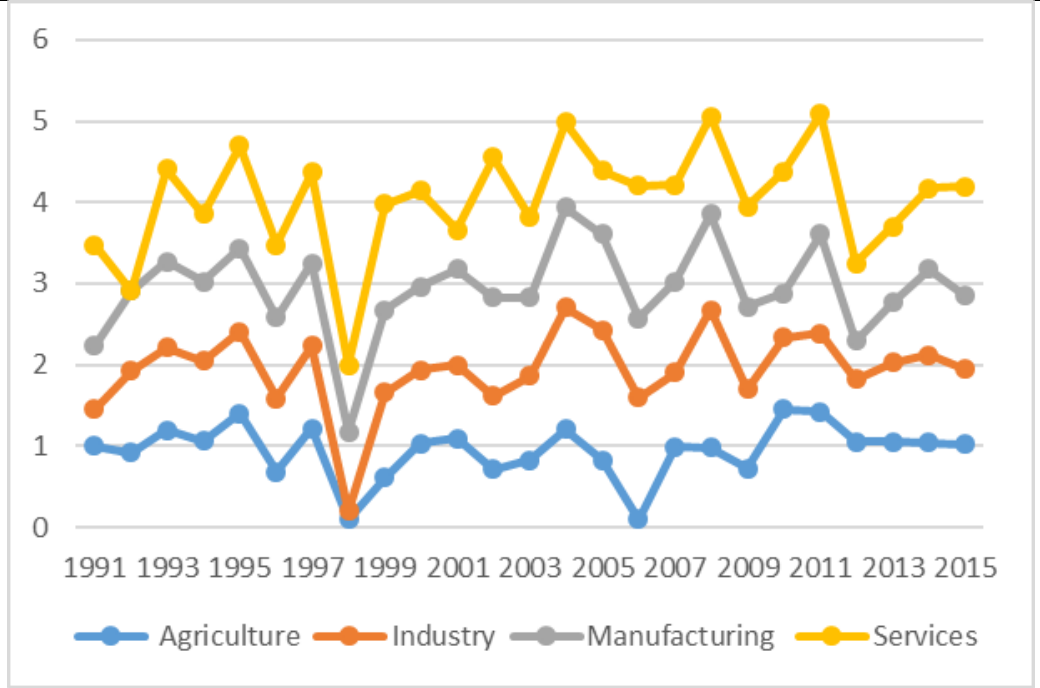

Figure 9: Growth of labor productivity by sectoral level (1991-2015)

Source: The World Bank, 2018

However, during the last six years, the growth of productivity was stagnated in agriculture, while it was declined in industry and manufacturing sector. The service sector shows increases in productivity growth. The sectoral composition of total output and employment in the Sudanese economy has changed from agriculture and manufacturing to service sector.

\subsection{Constraints hold Development back in Sudan}

The questions challenging policy sitters in Sudan are how industrial policies should be designed and how they can be implemented more effectively, and why service sector is so large relative to other sectors. On the other hand, the multiple administrative costs related production and the lower total factor productivity for labor in agriculture, lower levels of investment by private sector remain the main constraints for Sudanese commodities to be competitive in international markets. However, the lack of access to the international markets, lack of entrepreneurs and information and public institution-building, which needs to be more proactive government to cope with this market failure and to support the structural change.

The decline in agriculture and petroleum sectors employment associated with the internal immigration and secession of South Sudan have been the major challenges of Sudan's economy. However, in Sudan and during the last three decades, the service sector shares on average 42.8 percent of value added. It also shares 41.6 percent of total employment, this due to the public sector in Sudan is very large and most of employment opportunities have become concentrated in the non-manufacturing sectors. For instance, study carried out by Nour (2011) on the job opportunities in Sudan, asserted that the opportunities have focused on service sector such as education, health care, public sector and financial institutions.

The secession of South Sudan in 2011 has been causing a shock to Sudan's economy and initiates policies for recovery through the five-year plan for economic reform 2014-2019. It becomes much clear the problem is not in sectoral policies, it seems in entire economic policies, the quality of institutions and regulatory constraints on private sector.

One of the main constraints that hold the development in Sudan back is low level of savings and misallocation of investment. Most of the financial resources have been allocated away from agricultural and industrial firms, which face a constraint in access to finance. Another 
constraint includes the irrational of government consumption, where the fiscal deficit increased by $73 \%$ from US2.6 billion in 2010 to US5.7 billion in 2014, and inflation rates jumped to $59 \%$ in 2015 from $28 \%$ in 2012. Other reasons why the service sector growing very fast is that the institutional framework has affected the flexibility of labor and product markets, which causes the propensity of setting up new businesses. The moving from agriculture to manufacturing needs high skilled labor, however, the mismatch between labor supply and job vacancies, qualification and skill level in manufacturing sector was one of the reasons associated with the growing role of services. However, the productivity per labor in service sector is very low, this can be justified to the arising of female participation; demographic shifts; and the process of urbanization.

According to structural change model, the share of the 'primary' or agricultural sector, in total output and employment, is expected gradually diminished while that of the 'secondary' or manufacturing sector increase. In Sudan, the service sector was expanding rapidly due the absence of proper policy to manage the initial stages of industrial development and reallocate the skilled labor to industrial and manufacturing sector since the service sector provides more job opportunities relevant to manufacturing sector which was not developed yet. However, the structure changes are a new phenomenon in Sudan, where the labors shift from agriculture to oil and from oil to services.

\section{Results and Discussions}

This section assesses and analyses which commodities have comparative advantage, and which period Sudan has experienced structural transformation under the context of NSE. The study used time series data from 1980 to 2016. At first, we adapt RCA and PAM methods to identify the agro-industry commodities that have comparative advantage. Then, we develop two measurements to calculate the structural transformation from agriculture to industry and nixes. The employment shares can be calculated by considering the number of workers or hours worked in the agricultural and industrial sectors.

\subsection{Measuring the Comparative Advantage}

In this study, we estimate the comparative advantage for Sudan's agricultural as raw materials (Cotton, Livestock and Gum Arabic) and the agro-industry commoditities (Sugar, Textiles, and Meat Processing) over the years from 2005 to 2014.

\subsubsection{Estimation Results of RCA}

From table 2, all the commodities were analyzed for export promotion; the agro-industry commodities had comparative advantage in producing meat processing and Sugar. The study found that wheat and textiles commodities did not have comparative advantages. For instance, the market value of sugar production was lower than its opportunity costs (the export parity price of $\$ 18$ per $50 \mathrm{~kg}$ relevant to the market price of $\$ 39$ per $50 \mathrm{~kg}$. (Sudan Central Bank, 2015). The answer for the fundamental question why is much profitable, is the lower of opportunity cost of labor, land, irrigation system, electricity fees, supported from the government. 
Table 2: Estimation Results of RCA for Agricultural and Agro-industry commodities

\begin{tabular}{|l|c|c|c|c|c|c|c|c|c|c|}
\hline \multicolumn{1}{|c|}{ Year } & 2005 & 2006 & 2007 & 2008 & 2009 & 2010 & 2011 & 2012 & 2013 & 2014 \\
\hline Cotton* & 4.24 & 5.37 & 5.83 & 4.07 & 5.92 & 4.39 & 3.71 & 4.01 & 3.93 & 4.05 \\
\hline Livestock** & 43.01 & 32.93 & 29.74 & 41.03 & 39.28 & 36.84 & 43.21 & 54.83 & 67.02 & 76.93 \\
\hline Gum Arabic & 212.47 & 153.59 & 102.64 & 312.41 & 348.74 & 243.44 & 115.29 & 7174.57 & 213.05 & 443.09 \\
\hline Groundnut & 0.938 & 0.043 & 0.935 & 0.758 & 0.278 & 0.084 & 0.989 & 1.032 & 0.984 & 0.992 \\
\hline $\begin{array}{l}\text { Leather } \\
\text { products }\end{array}$ & 1.994 & 0.843 & 0.842 & 1.038 & 1.082 & 1.025 & 3.006 & 3.927 & 2.731 & 3.082 \\
\hline Wheat & 0.992 & 0.757 & 1.003 & 1.047 & 1.728 & 2.738 & 2.073 & 1.092 & 1.204 & 1.187 \\
\hline Sugar & 2.784 & 3.028 & 2.801 & 3.392 & 4.812 & 3.728 & 3.338 & 2.83 & 5.732 & 4.079 \\
\hline Textiles & 0.738 & 0.017 & 0.894 & 0.782 & 0.738 & 0.831 & 0.081 & 0.062 & 0.899 & 0.901 \\
\hline $\begin{array}{l}\text { Meat } \\
\text { Processing }\end{array}$ & 2.839 & 2.718 & 2.002 & 2.831 & 4.783 & 4.637 & 5.829 & 4.038 & 4.109 & 4.472 \\
\hline
\end{tabular}

*The Cotton is not-carded and Cotton seed oil-cake.

**Including Camels, Cows, Sheep, and Goats.

\subsubsection{Estimation Results of PAM}

Table 4 illustrates the PAM sensitivity analysis of livestock enterprises. The table shows the sensitivity of most indicators to the main output price level. It also demonstrates the exchange rate, the yield and labor market distortion. The categories of parameters determine the sensitivity of each ratio. The value of the FCB is found extremely sensitive to the parity prince of the main output, while the DRC is found to be a large relevant to parity price of the main output. The level of distortion was affected the value of the indicators, which may prevail on the labor market. Compared to the previous studies, it influenced by the level of profitability ratios (equal to interest rates) in both social and private prices.

The shadow exchange rate significantly influence the social benefit-cost ratio. Therefore, to create added value, the well managing the resources is needed to social benefits. The table shows the relationship between the comparative advantage and the ratio of social price. For instance, the social price ratios were 0.638, 0.519, and 0.492, which mean that Sudan can save foreign exchange $0.638,0.519$, and 0.492 times more relevant to its costs by investing in these products.

This allows us to conclude that Sudan has comparative advantage for exporting livestock and leather products as raw commodities. In terms of agro-industries, Sudan have a lower opportunity cost in producing and exporting meat processing and leather need a promotion and updated technologies to make it more competitiveness. 
Table 4: Measures of Comparative Advantage for Livestock Enterprises

\begin{tabular}{|l|c|c|c|c|}
\hline \multirow{2}{*}{ Parameters } & \multicolumn{4}{c|}{ Indicators } \\
\cline { 2 - 5 } & FCB & DRC & EPC & EPS \\
\hline Main output private price & 0.650 & 0.053 & 0.638 & 0.647 \\
\hline Main output social price & & 0.638 & 0.519 & 0.492 \\
\hline Subsidy & 0.235 & & 0.942 & 0.716 \\
\hline Conversion rate & 0.502 & 0.201 & 0.338 & 0.528 \\
\hline Exchange rate & 0.196 & 0.438 & 0.526 & 0.302 \\
\hline Yield & 0.791 & 0.382 & 0.182 & 0.331 \\
\hline $\begin{array}{l}\text { Distortion on the labor } \\
\text { market }\end{array}$ & 0.208 & 0.758 & 0.083 & 0.279 \\
\hline
\end{tabular}

Financial Cost Benefit ratio (FCB), Domestic Cost Resources ratio (DRC), The Effective Protection Coefficient ratio (EPC), and the Equivalent Producer Subsidy (EPS)

Table 5: Measures of Comparative Advantage for Gum Arabic Enterprises

\begin{tabular}{|l|c|c|c|c|}
\hline \multirow{2}{*}{\multicolumn{1}{|c|}{ Parameters }} & \multicolumn{4}{c|}{ Indicators } \\
\cline { 2 - 5 } & FCB & DRC & EPC & EPS \\
\hline Main output private price & 0.885 & 0.904 & 0.994 & 0.926 \\
\hline Main output social price & & 0.904 & 0.988 & 0.968 \\
\hline Subsidy & 0.885 & & 0.942 & 0.954 \\
\hline Conversion rate & 0.885 & 0.904 & 0.903 & 0.941 \\
\hline Exchange rate & 0.868 & 0.857 & 0.935 & 0.981 \\
\hline Yield & 0.868 & 0.857 & 0.937 & 0.964 \\
\hline $\begin{array}{l}\text { Distortion on the labor } \\
\text { market }\end{array}$ & 0.868 & 0.857 & 0.653 & 0.958 \\
\hline
\end{tabular}

Financial Cost Benefit ratio (FCB), Domestic Cost Resources ratio (DRC), The Effective Protection Coefficient ratio (EPC), and the Equivalent Producer Subsidy (EPS)

For Gum Arabic production, Sudan has an absolutely comparative advantage in producing and exporting where it shares $80 \%$ of world export of Gum Arabic, especially with best 


\section{Macrothink Institute ${ }^{\mathrm{TM}}$}

climate for gum Arabic which would result in reducing the ratios of FCB. DRC was ranged from 0.904 to 0.904 , which means the production cost made it competitive in the international markets. If the government adopts and promotes an efficient trade policy, gum Arabic have a potential and promising and it can be processed instead of exporting as a raw material.

Table 6: Measures for Cotton Enterprises

\begin{tabular}{|l|c|c|c|c|}
\hline \multirow{2}{*}{ Parameters } & \multicolumn{4}{c|}{ Indicators } \\
\cline { 2 - 5 } & FCB & DRC & EPC & EPS \\
\hline Main output private price & 0.740 & 0.456 & 0.441 & 0.503 \\
\hline Main output social price & & 0.484 & 0.480 & 0.240 \\
\hline Subsidy & 0.771 & & 0.552 & 0.685 \\
\hline Conversion rate & 0.872 & 0.465 & 0.768 & 0.793 \\
\hline Exchange rate & 0.949 & 0.420 & 0.880 & 0.970 \\
\hline Yield & 0.963 & 0.528 & 0.995 & 0.986 \\
\hline $\begin{array}{l}\text { Distortion on the labor } \\
\text { market }\end{array}$ & 0.973 & 0.678 & 0.708 & 0.699 \\
\hline
\end{tabular}

Financial Cost Benefit ratio (FCB), Domestic Cost Resources ratio (DRC), The Effective Protection Coefficient ratio (EPC), and the Equivalent Producer Subsidy (EPS)

Table 6 illistrates the cotton was produced by lowere cost, where cotton was adopting improved and potential sector, where FCB and DRC were strong relative the private prices and distortion on the labor market ( 0.740 and 0.973 , respectively). The table also shows how subsidy made cotton enterprises much effective. The major subsidy was a major taxation given the pan-territorial price system used across Sudan.

The results presented in table 7 shows the parameters of comparative advantage sugar enterprises, where the processing technology for sugar is a large mill. The sugar is produced for both local and foreign markets, where sugar production in Sudan has a comparative advantage. The DRC vary from 0.453 for the private price, to 0.801 due to the effect of exchange rate. However, as mentioned earlier that from the total manufacturing sector, agro-industries share for any major variables, such as employment (85\%), production (90), exports (53), and imports (42). This indicates to the fact that industrial sector heavily depends on agricultural sectors. It can be notice the sensitivity of sugar manufacturing to the costs of marketing and it was particularly sensitive to wages, where the comparative advantage is affected by many factors, this revealed that Sudan had had a comparative advantage in producing sugar. 
Table 7: Measures of Comparative Advantage for Sugar Enterprises

\begin{tabular}{|l|c|c|c|c|}
\hline \multirow{2}{*}{ Parameters } & \multicolumn{4}{c|}{ Indicators } \\
\cline { 2 - 5 } & FCB & DRC & EPC & EPS \\
\hline Main output private price & 0.162 & 0.453 & 0.521 & 0.482 \\
\hline Main output social price & & 0.283 & 0.738 & 0.319 \\
\hline Subsidy & 0.018 & & 0.743 & 0.237 \\
\hline Conversion rate & 0.293 & 0.464 & 0.281 & 0.311 \\
\hline Exchange rate & 0.581 & 0.802 & 0.672 & 0.873 \\
\hline Yield & 0.491 & 0.587 & 0.237 & 0.726 \\
\hline $\begin{array}{l}\text { Distortion on the labor } \\
\text { market }\end{array}$ & 0.503 & 0.482 & 0.182 & 0.492 \\
\hline
\end{tabular}

Financial Cost Benefit ratio (FCB), Domestic Cost Resources ratio (DRC), The Effective Protection Coefficient ratio (EPC), and the Equivalent Producer Subsidy (EPS)

Table 8: Measures of Comparative Advantage for Meat Processing Enterprises

\begin{tabular}{|l|c|c|c|c|}
\hline \multirow{2}{*}{ Parameters } & \multicolumn{4}{c|}{ Indicators } \\
\cline { 2 - 5 } & FCB & DRC & EPC & EPS \\
\hline Main output private price & 0.745 & 0.556 & 0.581 & 0.764 \\
\hline Main output social price & & 0.684 & 0.723 & 0.533 \\
\hline Subsidy & 0.471 & & 0.531 & 0.621 \\
\hline Conversion rate & 0.572 & 0.465 & 0.542 & 0.672 \\
\hline Exchange rate & 0.649 & 0.495 & 0.854 & 1.105 \\
\hline Yield & 1.123 & 0.826 & 0.725 & 1.225 \\
\hline $\begin{array}{l}\text { Distortion on the labor } \\
\text { market }\end{array}$ & 1.261 & 0.678 & 0.896 & 0.618 \\
\hline
\end{tabular}

Financial Cost Benefit ratio (FCB), Domestic Cost Resources ratio (DRC), The Effective Protection Coefficient ratio (EPC), and the Equivalent Producer Subsidy (EPS) 


\section{Macrothink}

The processing and production of meat is particularly advantageous in Sudan. The domestic cost resources ratio has the highest net social profit (0.556). Because the livestock sector was protected for long time, the EPC ratio was shown strong value at $(0.581)$, which implies that many meat-processing enterprises have good machineries and equipment.

Table 9: Measures of Comparative Advantage for Textiles Enterprises

\begin{tabular}{|l|c|c|c|c|}
\hline \multirow{2}{*}{ Parameters } & \multicolumn{4}{|c|}{ Indicators } \\
\cline { 2 - 5 } & FCB & DRC & EPC & EPS \\
\hline Main output private price & 1.483 & 1.549 & 1.540 & 1.684 \\
\hline Main output social price & & 1.732 & 1.592 & 1.861 \\
\hline Subsidy & 1.661 & & 1.708 & 1.574 \\
\hline Conversion rate & 1.754 & 0.798 & 0.901 & 0.711 \\
\hline Exchange rate & 1.965 & 1.968 & 1.569 & 1.245 \\
\hline Yield & 1.606 & 0.475 & 0.725 & 0.865 \\
\hline Distortion on the labor market & 1.380 & 0.302 & 0.475 & 0.748 \\
\hline
\end{tabular}

Financial Cost Benefit ratio (FCB), Domestic Cost Resources ratio (DRC), The Effective Protection Coefficient ratio (EPC), and the Equivalent Producer Subsidy (EPS)

Source: computed from the survey data.

Textile industry does not have a comparative advantage, where the FCB was ranged from 1.483 to 1.380 , wich was higher than 1 . In contrast, the DRC wwas also higher, for instance 1.549 was output private price. The lowest o distortion on the labor market can be explained by he avialabilty of labor skills.

\subsection{Empirical Results of Structural Transformation}

Table 10: Decomposed Productivity Growth, Sudan 1980-2010 (4 sectors)

\begin{tabular}{|c|c|c|c|c|}
\hline & \multicolumn{2}{|c|}{ Labor Productivity } & \multicolumn{2}{c|}{ Component of annual growth (\%) } \\
\cline { 2 - 5 } & $\begin{array}{c}\text { At start year } \\
\text { 2000 PPP USD }\end{array}$ & $\begin{array}{c}\text { Growth annual } \\
\%\end{array}$ & Within 4 sectors & Structural 4 sectors \\
\hline $1980-1990$ & 540.4 & -0.4724 & -0.2052 & -0.1486 \\
\hline $1991-2000$ & 362.1 & 2.7771 & 0.1452 & 0.1005 \\
\hline $2001-2010$ & 851.7 & 3.9731 & 2.7536 & 2.0418 \\
\hline $2011-2015$ & $2,041.24$ & 5.0727 & 3.5127 & 2.4785 \\
\hline $1980-2000$ & 455.5 & 1.075 & 0.9785 & 0.4756 \\
\hline $2001-2015$ & $1,248.2$ & 4.3396 & 3.0248 & 2.8045 \\
\hline
\end{tabular}

Sectors are Peroluim, Service, Manufacturing and Agriculture.

Generally the productivity growth in Sudan is low, but it steadily growing especially during the period from 2011 to 2015 due to the internal immigration from rural areas, where the productivity of farmers is increased, which can be notice during 2001-2015, the average growth of productivity was improved by $4.34 \%$ due to the discovery of oil which contribute to GDP. In contrast, the structural change component was positive and has become more important after the years 2000 driven by oil and mining sectors. However, between 2001 and 2010 , overall labor productivity growth annually increased to 3.9 percent. 
Table 11: Components of labor productivity change, 1980-2014

\begin{tabular}{|l|c|c|c|c|}
\hline \multirow{2}{*}{ Growth Decomposition } & \multicolumn{4}{|c|}{ Time periods } \\
\cline { 2 - 5 } & $1980-2000$ & $2000-2005$ & $2005-2010$ & $2010-2014$ \\
\hline (excluding oil) & & & & \\
\% annual productivity growth of & 0.6 & 2.7 & 3.1 & 0.8 \\
which: & 1.4 & 2.5 & 2.9 & -3.6 \\
$\quad$ \% within-sector productivity & 0.1 & -0.3 & -0.7 & -4.1 \\
$\quad$ \% structural change & & & & \\
\hline $\begin{array}{l}\text { (including oil) } \\
\text { \% annual productivity growth of } \\
\text { which: }\end{array}$ & 2.5 & 6.9 & 10.3 & -1.8 \\
$\quad \%$ within-sector productivity & -2.1 & 3.8 & 5.3 & -1.4 \\
$\quad \%$ structural change & & & & \\
\hline
\end{tabular}

Source: World Bank (2018), Nor (2011), ERF ST Data Base (2017) and author calculation (2018).

On the other hand, productivity growth was increased to 2.04 percent per year within sector, and structural change a drag on overall productivity growth. Indeed, there was almost no change in the share of employment industrial, while in the agricultural sector the share of employment has declined to 10 percent between 2000 and 2015. Structural change index (SCI) is used to estimate various indices to investigate which period experienced structural change over the period from 1980-2015. The indices as shown in figure 9 suggest that structural change was high during 2000s, where the share of employment in petroleum sector rapidly increased. The table also shows the shares of agriculture declined into its lowest levels.
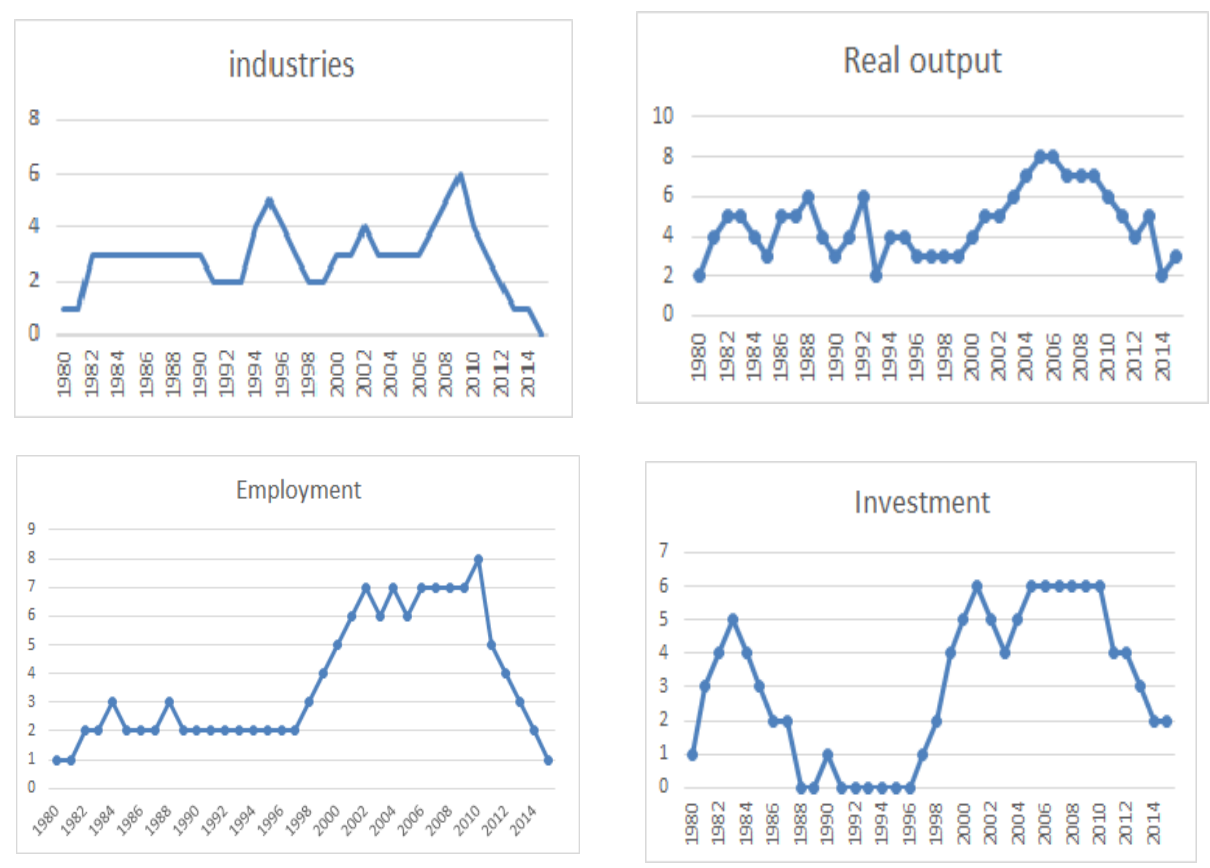

Figure 9: Structural change indices 1980-2015

Source: calculated by author, data from the World Bank and IMF, 2017 
As shown in the previous paragraph that the Sudan's economic structure was stable during the years from 1990-2012, which witnessed stable prices and steady economic growth. However, since the independence of South Sudan in 2011 the rate of structural change across the sectors has been the lowest, where Sudan lost roughly $75 \%$ of oil revenues, as a results many workers have lost their jobs, which decreases the real output and investment. More recently, there are some factors may drive structural change of Sudan economy, including economic reform, deindustrialization, skills labor and technical change.

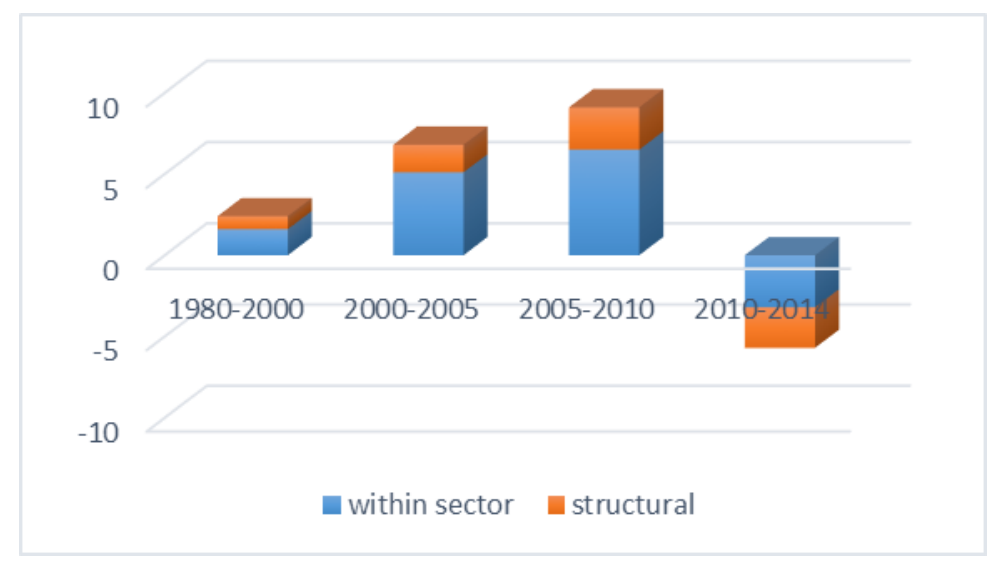

Figure 10: Labor productivity growth decomposition, by decade, 1980-2014

Source: World Bank (2018), Nour (2011), ERF ST Data Base (2017) and author calculation (2018)

Figure 10 illustrates the productivity per worker over the years from 1980-2014. The labor productivity with sector has increased by from $1.4 \%$ between 1980 and 2000, while after 2000 till 2010 it increases rapidly to over $5.8 \%$ with sector. There was structural change during the years 2000 and 2010, where the labor productivity increased from $2.1 \%$ to $2.9 \%$ respectively. The economic activity has shifted out from agricultural activity to petroleum over the years from 2000 and 2010. However, in 2012, petroleum contributes 25\% of GDP and $7.3 \%$ of total employment, but this has changed in the years coming after 2012, where the productivity per labor declined to the negative level $-3.9 \%$ with sector. This implies the structural change has negative impacts on Sudan's economy as a whole especially the years followed the independence of South Sudan. We present structural change for industrial, agricultural and service sectors by using the shares of employment and the shares of these sectors in value added with data over the entire period from 1980-2015.

Table 12: Time Series Data Analysis Agriculture, Manufacturing, and Service 1980-2015

\begin{tabular}{|c|c|c|c|}
\hline Dependent variable & $\begin{array}{c}\text { Agricultural } \\
\text { share in value } \\
\text { added }\end{array}$ & $\begin{array}{c}\text { share of } \\
\text { industry in } \\
\text { "value added" }\end{array}$ & $\begin{array}{c}\text { Share of service } \\
\text { in "value } \\
\text { added" }\end{array}$ \\
\hline log GDP per capita & $\begin{array}{c}0.043 * * \\
(0.001)\end{array}$ & $\begin{array}{c}0.043 * \\
(0.221)\end{array}$ & $\begin{array}{c}0.078 * * \\
(0.001)\end{array}$ \\
\hline
\end{tabular}

Significance level is indicated by $* p<0.05, * * p<0.01$. 
The results in table 12 illustrates the relationship between dependent and independent variables. The agricultural share in value added was significant with GDP per capita, which implies the agriculture has enhanced GDP per capita. Similarly, the share of service in value added was also significant and positively improved the GPD per capita and there is increasing the share of employment in this sector during the last two decades. The industry output was not significant with per capita income, which indicates to the fact that labor productivity was not improved due to the lack of skills and depreciation of machineries and innovation policy. This finding explains the lower skilled labors and why the government should adopt the best form of education strategy that will develop the skills and technology indicators of new graduates in line with the suggestions of Nour (2011) who pointed out that there is a lack of skills among labor in manufacturing sector; cooperation between $\mathrm{R}$ and $\mathrm{D}$ institutes and firms.

We conclude that the structural change has no effect on output of industrial and manufacturing sectors, our null hypothesis was accepted that the movement of labors from agricultural to the modern sectors was not enhanced the output of industrial sector and the labors are involved in non-agricultural activities. This result confirms our previous study, which indicates the lack of government policies to provide incentive to the private sector and encourage it to produce more, this will reduce the unemployment and stimulate economic growth.

Compared to previous results, the agro-industrial sector in Sudan shares $85 \%$ from over all industrial output, this indicates that the using of machinery and equipment are not developed yet to benefit from the added value, for instance, the food manufacturing shares around $90 \%$ of total value added of manufacturing sector, which needs a response from the government to encourage and support and protect these industries. However, the basic correlations from the above data revealed that areas where agro-industries and agricultural sectors are experienced a decrease in output per worker and a increasing in labor intensity in non-productive sectors while industrial employment declined. These findings are consistent with the out predicted analysis in the way that most of labors are moved from agricultural activities to manufacturing and modern sector, more specifically to oil sector, although it says the technology reduces labor demand in all sectors, but in Sudan this fact are not working well with agricultural sector and most of the labors reallocation towards non-manufacturing activities.

Our empirical strategy depends on the assumption that agro-industry commodities can be traded and replaced by the agricultural commodities as raw materials to the foreign markets. We also investigate whether the agro-industries lead to structural transformation especially to manufacturing sector. As illustrated above, the major reason resulting in poor productivity and missed the opportunity to develop both the agricultural and industrial sectors lie in the fact human capital has a lack of incentives to learn modern technologies. When analyzing implications of policy for economic development, it is worthwhile to learn from the experience of successful economic development. South Korea and New Industrialization Countries (NICs), among others, are proper examples. Among these countries, we are familiar with the fact that South Korea has expanded its economy from poor to more modern industrialized country. Recently, Sudan is increasingly renewing interest in designing a proper industrial policy, given the successful example from the East Asia countries, which demonstrates and implementing these policies. However, it allows me to argue that the role of governments in these countries helping in pursuing well-industrial policies, which might not work in Sudan due to the fact that the deficiencies and lack of governance. This argument goes in line with Stiglitz \& Greenwald (2013), pointed out that an effective industrial policy 


\section{Macrothink}

Research in Business and Management

ISSN 2330-8362

will work in countries with significant deficiencies in governance. They refer to this fact; it succeeded in some cases to correct market and government failures.

As mentioned earlier, the potential of agro-industries will be linked to agricultural and industrial structures, besides the availability of skilled labors, which may progress the industrialization process. The developing of agro-industries may help Sudan to encourage the agricultural sector to grow and sustain the industries by the raw materials. In this context, there is a need for small and medium scale agro-industries to be developed; this may complete the current and existing weak linkages between agricultural and industrial sectors and thereby helps in structural change.

Although Sudan has been experiencing a growth during the past decade that enhances structural transformation, the manufacturing sector was observed fastest change, where the share of employment increased by $15 \%$ for the years from 2005-2012. The capital-labor ratio in the non-productive sectors has grown very rapidly due to a lack of investment and the weak linkages between education and these sectors. This may expand the technological change and thereby reduce the structural transformation. For Sudan to benefit from the human capital there is a need to speed up structural transformation is to move away from exporting agricultural as raw materials and creates tradable sector based on comparative advantage of agro-industry commodities. Moreover, it is necessary to enhance labor mobility by improving labor skills and maintain the best business investment environment.

In Sudan the developing the agro-processing is the key to take-off since the agriculture has been a crucial for economic growth, especially livestock and its products, Gum Arabic, Cotton, among others would provide the opportunity for export. However, over the last two decades, there has been a significant transformation of Sudanese trade in natural resources including crude oil and the agricultural output was declined. The productivity of labor in Sudan is very low and there is a need for upgrading skills, besides that economic policy is far from benefiting from existence skilled labor, who are now involved in non-productive sectors. However, to get the benefit from the skilled labor and educational output, three focus reforms should be implemented at the same time, education reform, government reform, and economic policy reform.

It can be noted that Sudan over the past years are focused on balance growth where the industrial policy was promoted all industries to grow together. We suggest that Sudan to follow unbalanced growth due to the fact the capital is limited, different rate of return among investments, and reorganize the industry structure is impossible with balanced growth. However, Sudan has a big potential in agriculture and manufacturing, due to the possibility of agriculture surplus and there labor is a surplus in the rural areas, then the priority will be on Agro-Industries. However, it becoming necessary for Sudan to upgrade the agricultural value chain and developing the agro-industries, which considered as a key to take-off. Sudan has to focus on the agricultural commodities that provide opportunities for export. Due to the trade in agriculture heavily depends on industrial capabilities; there is a need for government to intervene in promoting agro-industry and agribusiness to support the weakness of private sector to upgrade value chain for exports, where has been facing difficulties in growing and competing with foreign commodities.

Based on the above results, we conclude that agro-industries are the best strategy to transform Sudan economy from agrarian to industrial and manufacturing base as depends on resource-based. In this context, the current industrial policy was designed to lead economic growth in Sudan. The share of agro-industries is on rise after the recent initiatives carried out by ministry of industry to localize many industries especially agricultural based. We also 
found the technological capability in most of the industries was significant and supporting comparative advantage, which may lead to structural Transformation in Sudan.

\section{Conclusion and Policy Implications}

This study has attempted to identify the priorities of Sudan's agro-industry commodities as a process of structural transformation. The study has also postulate that in order for Sudan to benefit from the availability human and natural resources by promoting economic policy to raise the labor productivity and facilitate the private sector to lead the industrial and manufacturing sectors. The study illustrates the background of the study, building two models to identify the comparative advantages of both agricultural products as raw materials and agro-industries commodities that Sudan has been focusing on, combining the theoretical with empirical perspectives. While in section tow, we provide an overview the constraints that hold development back in Sudan's and policies could be adapted to develop the comparative advantages of agro-industries. In particular, we present an involvement of private sector in agro-industries in Sudan, and we extends our analysis the constraints that hold back development in Sudan. In addition, we shed some lights on the role of agro-industries to accelerate economic growth and sustained the development. We also present our empirical models and discuss the estimated results to give implications to the policy makers to follow the structural change towards development. In particular, we have constructed the neoclassical approach to address the issue regarding the development of agro-industry and the possibility of a takeoff from this lower productivity and misallocation of the resources. The study has applied two methods to identify the trends of structural change in Sudan during the past decades. First, the RAM and RCA were considered to identify the comparative advantage of Sudan's agro-industry commodities for the recent period from 2005-2014. Second, we built a theoretical analysis to examine the sectoral composition trends of output and employment over the years from 1980-2016.

Many of the hypotheses were supported. Our major findings can be summarized in this section. We find that overall; the agricultural products (Gum Arabic, livestock, Cotton, and leather) had comparative advantages. We discussed the possibility of takeoff from the agro-industries as Sudan is considered as having a comparative advantage in agricultural products. While the agro-industry commodities had comparative advantage in producing meat processing and Sugar, we found that the wheat and textiles do not have comparative advantage. We have argued that although agriculture has remained the main source of employment and income, we observe a significant shift in the labor allocation from agriculture and engaging in non-manufacturing activities. The findings of this study indicate that in most cases, Sudan's only the agricultural commodities are consistent with their comparative advantage. The findings of this study build upon and support the findings of previous studies on comparative advantage of agricultural products (Imad-Eldin et al., 2010; Elryah, 2015). Sudan had a comparative advantage in Gum Arabic and Cotton.

Further analysis reveals that Sudan has been experiencing a negative structural change during 2001-2015. It had a positive impacts and contributed to growth in Sudan especially after the 1997 economic reforms, especially the construction manufacturing and services industries, with negative effects on agricultural sector between 2001 and 2011. The agricultural and service sectors were continued generating overall growth in 1980-2000, while the within-sector during 2000-2010, the structural change had a positive impacts on industrial sector, but the years followed the secession of South Sudan, the structural change had negative impacts on both agricultural and manufacturing sectors. The reallocation of employment away from agriculture toward service industries played a negative role, where the services sector was found the most dynamic sector and shape the Sudan's economic 


\section{Macrothink}

Research in Business and Management

ISSN 2330-8362

activity, where most of labor forces are involved in service sector. The share of industrial sector in total employment and total output has declined during 2001 and 2015. These findings confirm Lin \& Chang (2009) and McMillan (2011) hypotheses that developing countries should focus on manufacturing sector which will create greater employment opportunities and allowing country to increase the productivity. Further analysis reveals that structural change has a negative impact on Sudan's economy and growth of labor productivity, the share of service in output has steadily increased, reflecting reallocation of employment away from agriculture toward service industries played a negative role, where the services sector was found the most dynamic sector and shape the Sudan's economic activity, where most of labor forces are involved in service and trade activities. The findings of this study change our understanding of structural change in developing countries, this research is of broad significance to researchers and policymakers in the fields of agriculture, industry and manufacturing.

These findings have important implications for the industrial and trade policies and institutions on developing the comparative advantages of agro-industries. Given these findings, some policy recommendation that emerge are:

1. Promoting economic policy aiming to support agro-processing and develop the commodities having a probability of a comparative advantage to compete in international markets. In this manner, there is a more potential gain in taken into their consideration efficiency of these commodities to capture the largest market shares. Increasing the productivity from these commodities chains could be achieved, for example, through the improving linking agriculture with industry and supports the medium and small scale industries that use the agricultural raw materials for exports. The high probability for these commodities to enhance comparative advantage in the international markets will be sustained if the policy makers continue their support to the agro-industry sector.

2. Transforming industrial sector by developing technological incubators to industrial parks. In Sudan, the concept of developing technological incubators started in the early 2000s in a way that to develop skills and knowledge and provide industries with high skilled labors.

3. Focusing on agro-processing commodities for export, for instance, industry, Gum Arabic, feeds, Sugar, livestock, oil vegetables, and textiles to achieve higher growth and thereby increase the contribution of agro-industry to the GDP. Given the availability of raw materials and skilled labors, the potential of agro-industries will transform the Sudan's economy into high value added by promoting the export policy. Technological incubators has a major impact on providing industrial with high skilled labor; it develops the new small businesses.

4. Adjusting the agro-industries trade to export final industrialized commodities to benefit from the added value instead of exporting these commodities as raw materials. The current economic reform policies and the five-year economic program of the 2015-2019 result in a contribution to the GDP by selecting industrialization and manufacturing and some other agricultural commodities as engine for economic development. However, these commodities are exported as raw materials and it would be able to compete in the international markets, livestock, Cotton, and Gum Arabic are the most commodities have comparative advantages.

5. Adapting unbalanced growth strategy and the investment should be concentrated on agro-industries. There is a need for reforms in education, government and economic policy due to the fact that Sudan is lack of absorption capacity especially capital for SMEs which considered one of the main constraints. It's recommended that Sudan's option is to follow step-by-step in developing agro-industries in the early stage and catching up the forerunners. 
There are a number of constraints on productivity in the agricultural sector, including a lack of innovation and industrial infrastructure. Without those constraints, the transition out of primary commodities to higher productivity sectors may well have been higher, and the removal of those constraints could induce a larger structural shift in the future.

Our analysis suggests a need to explore further what constraints productivity and exports. Future research might focus on technological innovation capabilities and entrepreneurship in SMEs.

\section{Acknowledgements}

The author expresses his gratitude to directors of INSE for their guidance and supports. The author gratefully thanks Dr. Junjie Xia for his comments on the mid-term version. Special thank goes to prof. Lin and Prof. Wang for their suggestions and comments on the final presentation during the conference meeting. Thank you for your deep academic insights and suggestions.

\section{References}

Ahmed, E., et al. (2012). Mechanism of Poverty Incident in Agricultural Sector of Sudan. Journal of Development and Agricultural Economics, 4(14) , 371-383.

Ahmed, M. M. (2010). Sudan Phase 2. London: Overseas Development Institute (ODI).

Ali, A. A. (2009). On the Challenges of Economic Development in Post-Conflict Sudan. Journal of Arab Planning Institute.

Andrei A. Levchenko and Jing Zhang. (2014). Ricardian Productivity Differences and the Gains from Trades. European Economic Review, 65, 45-65.

Andrei A. Levchenko and Jing Zhang. (2016). The Evolution of Comparative Advantage: Measurement and Welfare Implication. Journal of Monetary Economics, 78, 96-111.

Anthony Bebbington, T. B. . (2013). Political Economies of Agro-industry: From Documenting Complexity to Informing Current Debates Introduction to Development and Change Virtual Issue 2. Development and Change, 00(0), 1-16.

Balassa, B. (1977). Revea Comparative Advantage Revisited: Analysis of Relative Export Shares of the Industrial Countries 1953-1971. The Manchester School, 45, 327-344.

Barro, R. J., and X. Sala-i-Martin . (1995). Economic Growth. Massachusetts : Massachusetts Institute of Technology Press .

Benhabib, J. and M. M. Speigel . (1994). The Role of Human Capital in Economic Development: Evidence from Aggregate Cross-country Data. Journal of Monetary Economics, 34(2), 143-173.

Bernard Andrew B., Jonathan Eaton, J. Bradford Jensen and Samuel. (2003). Plants and Productivity in International Trade. American Economic Review, 93, 1268-1290 .

Borensztein, E., J. De Gregorio and J. W. Lee. (1998). How Does Foreign Direct Investment Affect Economic Growth? Journal of International Economics 45(1), 115-35.

Brandt, L., Hsieh, C., \& Zhu, X. . (2008). Growth and Structural Transformation in China". In L. B. (Eds.), "China's Great Economic Transformation (pp. 683-728). Cambridge: Cambridge University Press. doi:10.1017/CBO9780511754234.018.

CHIKAMAI, B.N., W.B. BANKS, D.M.W. ANDERSON and W. WEIPING . (1996). Processing of gum arabic and some new opportunities. Food Hydrocolloids 10 (3), 309-316. 
Cripps, T.F. and Tarling, R.J. (1973). Growth in Advanced Capitalist Economies 1950-70. Cambridge : Cambridge University Press.

Curtis, C. C. (2016). Economic reforms and the evolution of China's total factor productivity. Review of Economic Dynamics, 21, 225-245.

David Damiyano and Macleans Mzumara . (2013). Is it Oil only that Matters in Sudan's Foreign Sector? Greener Journal of Economics and Accountancy, 2(2), 62-67.

Deardorff, A. V. (2010). Thoughts on Revealed Comparative Advantage. OECD Global Forum on Trade Chengdu. Beijing, China: OECD Global Forum on Trade Chengdu.

Dekle, Robert and Vandenbroucke, Guillaume. (2009). A Quantitative Analysis of China's Structural Transformation. Journal of Economic Dynamics and Control, 36(1), 1-168.

Duarte, M. and Restuccia, D. . (2010). The role of the structural transformation in aggregate productivity. The Quarterly Journal of Economics, 125(1), 129-173.

Elryah, Y. (2015). Back to the Agriculture - the Development of the Comparative Advantage of Sudan's Commodities. Journal of Finance and Economics, 3(1), 1-5.

F., R. (1928). A mathematical theory of saving. The Economic Journal, 38(152), 543-59.

Fagerberg, J,. and B. Verspagen . (2002). Technology-Gaps, Innovation-Diffusion and Transformation: an Evolutionary Interpretation. Research Policy, 31, 1291-304.

FAO. (2014). Information System on Water and Agriculture . Khartoum, Sudan: Food and agriculture of the United Nation (FAO).

Felipe, J. (1999). Total factor productivity growth in East Asia: A critical survey . Journal of Development Studies, 35(4), 1-41.

Gisselquist, R. M. (2015). State capability and prospects for close coordination Considerations for economic policy in Africa. WIDER Working Paper 2015/035 World Institute for Development Economics Research, 1-16.

Gollin, D., R. Jedwab and D. Vollrath . (2016 ). Urbanization with and without Industrialization. Journal of Economic Growth, 21(1), 35-70.

Hag, A. (1997). Export Performance in Sudan: Recent Trends and Policy Impact. Journal of Economic Cooperation among Islamic Countries 18(4), 57-76.

Herrendorf, Berthold, Christopher Herrington, and Akos Valentinyi. (2014). Sectoral Technology and Structural Transformation. American Economic Journal Macroeconomics.

IFAD. (2009). Republic of Sudan: Country Program Evaluation. Khartoum. 2060-SD: 136.: International Food Agricultural Development.

Imad Eldin Yousif, Azaria Elbushra, and Azhari Ibrahim. (2010). The Impact of the Economic Partnership Agreement with the European Union on the Agricultural Trade of Sudan. International Journal of Sudan Research, 1(1), 83-89.

Industry, S. M. (2005). The comprehensive industrial survey (Vol. 4). Khartoum: Sudan Ministry of Industry.

J., C. (1977). Modern Capitalism. Oxford: Martin Robertson.

J., M. M. (2003). The Impact of Trade on Intra-Industry Reallocations and Aggregate Industry Productivity. Econometrica, 71(6), 1695-725. 
JA, S. (1934). The Theory of Economic Development: An Inquiry into Profits, Capital, Credit, Interest, and the Business Cycle. Cambridge, MA: Harvard University Press.

Johnston, J. and J. DiNardo . (1997). Econometric Methods, 4th ed. New York: Scribd.

Jones, Charles and Paul M. Romer,. (2010). "The New Kaldor Facts: Ideas, Institutions, Population, and Human Capital". American Economic Journal: Macroeconomics, 2(1), 224-245.

Ju J, Lin J, and Wang Y. . (2015). Endowment structures, industrial dynamics, and economic growth. Journal of Monetary Economics, 76, 244-263.

JY, L. (2011). "New structural economics: A framework for rethinking development. . The World Bank Research Observer, 26(2), 193-221.

Kaikati, J. (1980). The Economy of Sudan: A Potential Breadbasket of the Arab World? . International Journal of Middle East Studies 11(1), 99-123.

Kaldor, N. (1967). Strategic Factors in Economic Development. Ithaca: Cornell University Press.

Kathuria V., and R. S. N. Raj. (2009). Is Manufacturing an Engine of Growth in India? Analyis in the Post Nineties. Paper for the UNU-WIDER/UNU-MERIT/UNIDO Workshop, Pathways to Industrialisation in the 21 st Century. New Challenges and Emerging Paradigms.

Kongsamut, Piyabha, Sergio Rebelo, and Danyang Xie. (2001). Beyond Balanced Growth. Review of Economic Studies, 68 , 869-882.

Krugell, W. \&. (2009). Measuring the Export Capability of South African Regions. Development Southern Africa, 26(3), 459-476.

Levine, R. (2005). Finance and Growth: Theory and Evidence. In P. Aghion and S. Durlauf (Eds.), Handbook of Economic Growth 1st ed (pp. 865-934). Amsterdam : Elsevier.

Lewis, W. A. (1955). The Theory of Economic Growth. Homewood, Illinois : Richard D. Irwin. .

Lin JY, and Chang HJ . (2009). Should industrial policy in developing countries conform to comparative advantage or defy it? A debate between Justin Lin and Ha-Joon Chan. Development Policy Review 27(5), 483-502.

Lin JY, and Monga C. . (2011). Growth identification and facilitation: The role of the state in the dynamics of structural change. Policy Research Working Paper 5313. World Bank. Washington, DC. .

Lin JY, and Treichel V . (2014). Transforming Economies: Making Industrial Policy Work for Growth, Jobs and Development. In N. I.-W. Salazar-Xirinachs JM, Making industrial policy work for development. . Munikh: International Labour Organiz.

Lin, J.Y., and H. Chang. (2009). DPR Debate: Should Industrial Policy in Developing Countries Conform to Comparative Advantage or Defy It? Development Policy Review, 27(5), 483-502.

Lucas, R. (1988). "On the Mechanics of Economic Development. Journal of Monetary Economics, 22(1), 3-42.

MACRAE, J. and G. MERLIN. (2002). The Prospects and constraints of development of gum arabic in Sub-Saharan Africa. Washington, D.C.: World Bank. . 
Masters W \& Winter-Nelson A. . (1995). Measuring the comparative advantage of agricultural activities: Domestic resource costs and the social cost-benefit ratio". American Journal of Agricultural Economics, 77, 243-50.

McMillan, M. and D. Rodrik. (2011). Globalization, Structural Change and Productivity Growth. In A. M. M. Bacchetta, Making Globalization Socially Sustainable (pp. 49-84). Geneva: International Labour Organization and World Trade Organization.

Miller, R.E., e P.D. Blair . (2009). Input-Output Analysis: Foundations and Extensions. Cambridge: Cambridge University Press, Second Edition.

Monga, C. (2012). The Growth Report and New Structural Economics . In J. Lin, New Structural Economics: A Framework for Rethinking Development (pp. 81-140). Washington DC: International Bank for Reconstruction and Development / International Developm.

Monke and Person . (1989). The Policy Analysis Matrix for Agricultural Development. Ithaca: Cornell University Press.

Morsy H., A. Levy and C. Sanchez . (2014). Growing Without Changing: A Tale of Egypt's Weak Productivity Growth. Working Paper Series, No. 940, . Economic Research Forum.

Nour, S. (2011). Assessment of industrial performance and the relationship between skill, technology and input-output indicators in Sudan. UNU-MERIT Working Papers.

Ranis G, and Fei JCH . (1961). A theory of economic development. The American Economic Review, 51(4), 533-65.

Ricardo, D. (1817). Principles of Political Economy and Taxation. London: John Murray.

Rodrik. (2013, November 19). Structural Change, Fundamentals, and Growth: An Overview. Retrieved from mimeo: http://j.mp/1HgaMHD

Rogerson, R. (2008). Structural Transformation and the Deterioration of European Labor Market Outcomes. Journal of Political Economy, 116 , 235-259.

Rui, H. (2005). Development, Transition and Globalization in China's Coal Industry. Development and Change, 36(3), 691-710.

S, K. (1979). Growth and structural shifts. In: Galenson W, ed. Economic Growth and Structural Change in Taiwan. The Postwar Experience of the Republic of China . London: Cornell University Press .

Stephen, K. (1990). Framers and Failure of Agribusiness in Sudan. Middle East Journal, 44(4), 649-667.

Stiglitz, J., J. Lin, C. Monga, and E. Patel. (2013). Economic Policy in the African Context. Washington, DC: Policy Research Working Paper, World Bank.

Taha, A. (2016). Economic aspects of the transformational industries, an evaluation study of Sudanese . Applied Economics and Finance, 3(3).

Todaro, M. A. (2011). Economic Development (11th ed.). Boston: Addison Wesley.

\section{Copyright Disclaimer}

Copyright reserved by the author(s).

This article is an open-access article distributed under the terms and conditions of the Creative Commons Attribution license (http://creativecommons.org/licenses/by/3.0/). 